\title{
Complementary Recognition in Condensed DNA: Accelerated DNA Renaturation
}

\author{
Jean-Louis Sikorav \\ Unité de Génétique et Biochimie du Développement \\ LA CNRS 361, Institut Pasteur \\ 25 rue du Docteur Roux, 75724 Paris Cedex 15, France \\ and George M. Church \\ Department of Genetics, Harvard Medical School and \\ Howard Hughes Medical Institute \\ 25 Shattuck Street, Boston, MA 02115, U.S.A.
}

(Received 26 April 1991; accepted 22 August 1991)

\begin{abstract}
The functional consequences of DNA condensation are investigated. The recognition of complementary strands is profoundly modified by this critical phenomenon. (1) Condensation of denatured DNA greatly accelerates the kinetics of DNA renaturation. We propose a unifying explanation for the effects of several accelerating solvents studied here including polymers, di- and multivalent cations, as well as effects seen with the phenol emulsions and single-stranded nucleic acid binding proteins. Optimal conditions for renaturation at or above the calculated three dimensional diffusion limit are theoretically consistent with a limited search space in the condensed phases. (2) In addition to these effects on association of two single strands, similar condensation acceleration effects can be secn in strand exchange cxpcriments with double stranded DNA without proteins. These may model a mechanism of recombinational protein function.
\end{abstract}

Keywords: excluded volume effects; phase transitions; genetic recombination

\section{Introduction}

The concept of complementariness (Pauling \& Delbrück, 1940) is central in molecular biology. In nucleic acids, the recognition of complementary strands is a key functional property, essential in biological processes such as replication, transcription and genetic recombination. In the present article we investigate two questions related to complementary recognition in nucleic acids: the question of the optimal conditions for DNA renaturation and the question of the physical basis of genetic recombination.

\section{(a) Renaturation of DNA: the optimization problem}

The kinetics of renaturation of DNA have been extensively investigated in the last 30 years (for a review, see Wetmur, 1976). DNA renaturation can be modeled as an irreversible second order reaction, characterized by a rate constant $k_{2}$. To optimize this reaction means to maximize the rate constant. The question of the optimization was first raised by Marmur \& Doty (1961) who investigated the effect of temperature on the rate of renaturation: optimal renaturation occurred at about $25^{\circ} \mathrm{C}$ below the denaturation temperature. This work and subsequent work on salt concentration effects on the rate of renaturation has led to the definition of standard conditions for renaturation $\left(68\right.$ to $70^{\circ} \mathrm{C}$, $1 \mathrm{M}-\mathrm{NaCl}$ : see Wetmur \& Davidson, 1968; Wetmur, 1976). How can we accelerate the rates of renaturation beyond this standard rate? According to the literature, we can think of three possibilities.

(1) The volume exclusion approach relies on the addition of inert polymers in the reaction mixture. These polymers act by reducing the volume of the solvent accessible to the DNA molecules, therefore increasing their local concentration. This steric effect is usually referred to as an excluded volume effect in polymer physics (Flory, 1953). Using molar concentrations of $\mathrm{NaCl}$ and high $(35 \%$ or more of 
the total volume) concentrations of dextran sulfate, Wieder \& Wetmur (1981) have achieved accelerations of 100 -fold of the renaturation rate. This volume exclusion approach has a possible biological significance. Indeed, over $25 \%$ of the Escherichia coli intracellular space is occupied by macromolecules (mostly proteins and RNA), which is similar to the concentration in macromolecular crystals (Minton, 1981, 1983). This volume occupancy (often referred to as macromolecular crowding) has major consequences on the structure and the functions of macromolecules (Zimmerman \& Harrison, 1987; Jarvis et al., 1990). Zimmerman and co-workers have undertaken the study of these consequences on the interactions of nucleic acids with themselves or with proteins (Zimmerman \& Harrison, 1987 and references therein).

(2) The second approach relies on the Phenol Emulsion Reassociation Technique (abbreviated PERT $\dagger$ ) described by Kohne and co-workers (Kohne et al., 1977). PERT is a two-phase system composed of water and phenol: denatured DNA and salt are added in the water phase. Shaking of the two phases creates a phenol/water emulsion and results in accelerations of many thousand fold of the rate of renaturation. The mechanism of this effect is not known and cannot be attributed to a decreased DNA melting temperature, because the rate of renaturation is only weakly dependent on temperature between $20^{\circ} \mathrm{C}$ and $56^{\circ} \mathrm{C}$. The reassociation very likely takes place at the phenol-water interface: this hypothesis is supported by the finding that singlestranded DNA is physically associated with the emulsion (Wieder \& Wetmur, 1982). Kohne et al. (1977) have mentioned the possible biological relevance of PERT, in particular for the problem of reassociation of DNA at physiological temperatures and the possible importance of similar systems in the acceleration of prebiotic synthetic reactions.

(3) The last approach relies on the use of singlestranded DNA binding proteins such as the gene 32 protein of phage T4 (Alberts \& Frey, 1970), the Escherichia coli single-stranded DNA binding protein (Christiansen \& Baldwin, 1977), the simian virus 40 large tumor antigen (Schiedner et al., 1990), the mammalian heterogeneous nuclear ribonucleoprotein Al protein (Pontins \& Berg, 1990), or the RecA protein (Weinstock et al., 1979). These proteins can catalyze the renaturation of DNA at physiological temperature. Their biological importance is well documented (see, for instance, Kornbery, 1980; Chase \& Williams, 1986; Cox \& Lehman, 1987).

\section{(b) Critical phenomena involving nucleic acids}

Let us consider the volume exclusion approach to the problem of the acceleration of renaturation

† Abbreviations used: PERT, phenol emulsion reassociation technique; $\mathrm{PEO}$, poly(ethylene oxide); bp, base-pair(s); DS, dextran sulfate rates: the reaction can be modeled as a fourcomponent mixture: two types of polymers (denatured DNA and the added polymer), a solvent (water) and salt $(\mathrm{NaCl})$. Several types of critical phenomena can be expected in such a system: the incompatibility between the two polymers can lead to a segregation of the two polymeric species; also we can expect a change of conformation of the denatured DNA molecules from a swollen state to a more compact configuration (Flory, 1953; de Gennes, 1985). In this article, we use the term critical for physical phenomena that result from infinitesimally small variations of an appropriate parameter (such as the temperature or the concentration of one of the components of the system). Examples of such critical phenomena in a fourcomponent mixture composed of native DNA, poly(ethylene oxide) (abbreviated PEO), water and $\mathrm{NaCl}$ have been described by Lerman and coworkers (Lerman, 1971; Jordan et al., 1972: see Figs 3 and 4 therein). The present article deals with two main types of structural transitions (which can occur as critical phenomena) involving nucleic acids. A schematic representation of these transitions is shown in Figure 1. The first type of transition is the helix-coil transition between native (doublestranded) and denatured DNA molecules. This transition has been extensively studied with DNA molecules in solution (transition $1 \leftrightarrows 2$ in Fig. 1 : for an introduction, see Cantor \& Schimmel, 1980). The second type of transition is the coil-globule transition. In the next sections we briefly describe this transition.

The coil-globule transition refers to the transition of a flexible polymer from an expanded roil configuration to a collapsed globular state. This transition is a major focus of interest in polymer science for experimentalists and theoreticians (for a review. see Williams et al, 1981). Flory (1953) has studied theoretically the evolution of the configuration of a neutral homopolymer with an unknown radius (i.e. root-mean-squared end-to-end distance) $R$, and a degree of polymerization $N$ ( $N$ is the number of monomers in the polymeric chain). In a good solvent, the pair interactions between two segments of a polymeric chain are repulsive and tend to swell the coil. The radius of the coil is determined by the sum of the repulsive energy and an elastic (entropic) energy, which prohibits large deformations. Flory (1953) found $R \sim N^{3 / 5}$ for dilute (non-overlapping) concentrations of the chain. More generally, if $d$ defines the dimensionality of the system, $R \sim N^{v}$. where $v$. called the critical exponent, is equal to $3 /(d+2)$ (de Gennes, 1985).

This relation $\left(R \sim N^{v}\right)$ provides a typical example of a scaling law, which is a power law characterized by its critical exponent $v$. In a poor solvent the segment-to-segment interactions become attractive and the complete collapse of the chain is hindered only by steric constraints. Two physical events can take place in an unfavorable solvent environment: collapse and/or aggregation. Polymer collapse refers to an intramolecular event, leading to a collapsed 


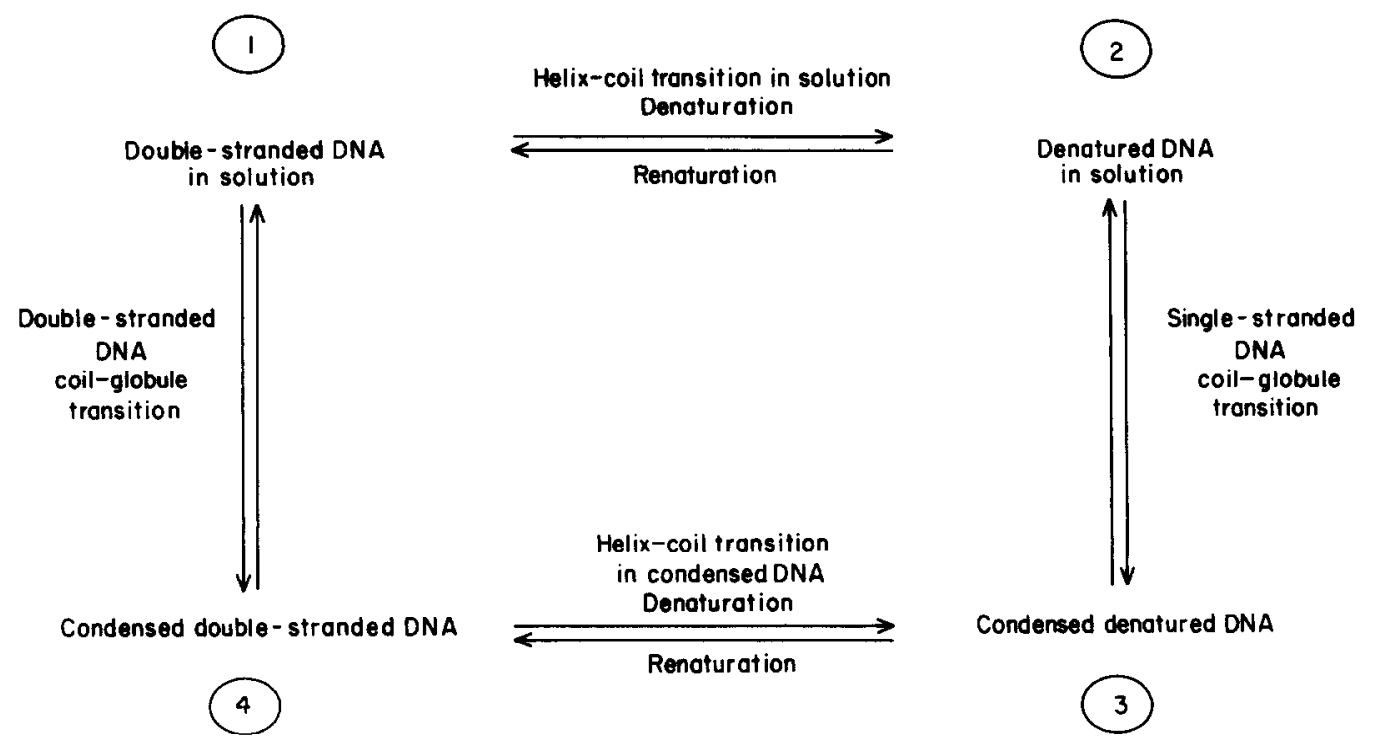

Figure 1. Schematic representation of the nucleic acid structural transitions studied in this article.

structure of a single polymer chain. For individual collapsed structures (called globules) one expects $R \sim N^{1 / 3}$ (and more generally $R \sim N^{1 / d}$, where $d$ is the dimensionality of the system (Williams et al., 1981; de Gennes, 1985). Individual collapse is the expected behavior for dilute (non-overlapping) solutions of polymers. Since the attractive interactions at the intramolecular level also exist at the intermolecular level, an unfavorable solvent environment can also lead to an aggregated polymer phase. Polymer aggregation refers to the co-existence of a solvent-rich phase (with a few contracted chains) and a second polymer-rich phase. Aggregation is expected to become more favorable at high polymer concentrations.

The coil-globule transition of polynucleotides has been investigated theoretically and experimentally by many authors. It differs from the coil-globule transition involving neutral homopolymers in several aspects: (1) polynucleotides are usually heteropolymers rather than homopolymers; (2) polynucleotides are charged polymers (polyelectrolytes); various cations can induce the coilglobule transition of double-stranded DNA in an aqueous solvent, e.g. $\mathrm{H}^{+}$(Dore et al., 1972), divalent cations (Knoll et al., 1986) or trivalent cations (Gosule \& Schellman, 1976; Widom \& Baldwin, 1983; see also Manning, 1989); (3) polynucleotides can be double-stranded or single-stranded: in the theoretical framework of the coil-globule transition, however, double-stranded DNA can be considered as a single-stranded stiff homopolymer chain (see Grosberg et al., 1982). The coil-globule transition of double-stranded DNA can therefore be described as a collapse from the non-compact form (the coiled state) to the compact form (the globular state); (4) polynucleotides are often lyotropic nematic polymers: the coil-globule transition of doublestranded or single-stranded DNA can be coupled to a disorder-to-order transition, an isotropic-liquid crystalline transition from the isotropic state to an anisotropic (mesomorphous) phase, undergone by many rod-like or semirigid polymers when their concentrations exceed a critical value (for an introduction to the physics of liquid crystals, see de Gennes, 1975).

We now turn back our attention to Figure 1. To distinguish the coil-globule transitions involving native DNA ( $\leftrightarrows 4$ in Fig. 1) and denatured DNA ( $2 \leftrightarrows 3$ in Fig. 1), we shall use the term doublestranded DNA coil-globule transition for the first transition ( $1 \leftrightarrows 4)$ and the term single-stranded DNA coil-globule for the second transition $(2 \leftrightarrows 3)$. Also, we shall use the terms condensation and condensed as generic terms covering the individual collapse of molecules as well as aggregated states, either for native or denatured DNA (we follow here Post \& Zimm, 1982). In contrast to the vast body of literature available on transitions $1 \leftrightarrows 2$ and $1 \leftrightarrows 4$, the two other transitions shown in Figure 1 have been less studied: the single-stranded coil-globule transition is nevertheless described in at least two publications: Dore et al. (1972) describe an acidic (protonation-induced) transition and Evdokimov et al. (1976) a polymer and salt transition. A helix-coil transition involving condensed DNA $(4 \leftrightarrows 3)$ is mentioned by Gosule \& Schellman (1976).

\section{(c) The relationship between excluded volume effects and critical phenomena}

We have observed above that the search of an excluded volume effect in DNA renaturation through the addition of inert polymers can lead to critical phenomena such as those found in genuine thermodynamic phase transitions (phase transitions are rigorously defined by the existence of discontinuities in derivatives of an appropriate thermodynamic potential: see Stanley, 1987, p. 17). More generally, there exists a strong analogy between 
polymer statistics and phase transition problems. A polymer solution is similar to a magnetic system: the chemical potential associated with the concentration of monomers corresponds to the temperature of the magnetic system, and the chemical potential associated with the concentration of polymers to the magnetic field (see de Gennes, 1985). As observed by de Gennes, the discovery of this relationship between polymer statistics and phase transition problems has allowed polymer science to benefit from the vast knowledge accumulated in phase transition studies; in particular a number of remarkably simple scaling properties (i.e. related to the size of the polymers by power laws) have emerged (for a recent and accessible review on scaling concepts, see Blumen \& Schnörer, 1990).

The importance of excluded volume effects in the theoretical existence of phase transitions in the structural transitions shown in Figure 1 is well documented:

Fisher (1966) has shown that, due to excluded volume effects, the helix-coil transition can be a phase transition in three or in two-dimensional systems.

Onsager (1949) has shown that the isotropic liquid crystalline transition can also be the consequence of excluded volume effects (due to shape asymmetry) alone: the intervention of intermolecular attractive forces is not required (a twodimensional analogy can be made to the ordering of logs floaling on a pond) (for a review, see Odijk, 1986).

In the case of the coil-globule transition, the importance of excluded volume effects is also clear (see Williams et al., 1981). However, the existence as well as the nature (first order or second order) of a phase transition is apparently still an open question among theoreticians.

\section{(d) DNA condensation as a possible means to optimize renaturation}

'The relationship between excluded volume effects and phase transitions prompted us to formulate the hypothesis that, since excluded volume effects could lead to a critical phenomenon (namely DNA condensation), conversely DNA condensation would increase the rate of DNA renaturation. This hypothesis was formulated as a working hypothesis more than as a true prediction. Indeed, if we consider a solution containing denatured DNA molecules in which we progressively increase the salt concentration, two opposite phenomena take place: increasing salt concentration decreases the repulsion between complementary strands and can increase the rate of renaturation. On the other hand, this effect also operates at the intramolecular level and can lead to an increased folding of denatured molecules (Studier, 1969a; Wilson et al., 1990), which may inhibit renaturation (Studier, 1969b). We expect the same two effects to act in condensed denatured DNA: the intermolecular effect should favor renaturation, while the intramolecular effect is likely to be unfavorable. Moreover, we must distinguish two situations: dilute and concentrated solution of denatured DNA. In dilute solution, individual coils are separated and do not overlap: individual collapse should precede aggregation. and renaturation should therefore involve fully collapsed chains. In concentrated solutions, on the contrary, overlapping of the coils is expected (at least in a three-dimensional system: see de Gennes. 1985). In this case, condensation would directly result in an aggregate of denatured coils, which would essentially retain their original (i.e. solution state) conformation. Whether any motion of these condensed denatured chains is possible is unknown: due to entanglement effects, a reptation process may be expected (de Gennes, 1985). For all these reasons is seems difficult to predict the consequences of condensation on renaturation.

We show, however, in the present paper that various experimental conditions that induce the condensation of double-stranded DNA also greatly accelerate the rate of renaturation of denatured DNA. The diversity of the conditions used the acceleration of renaturation can be induced by divalent cations (Knoll et al., 1986), trivalent rations (Gosule \& Sohellman. 1976; Widom and Baldwin, 1983), ethanol and $\mathrm{NaCl}$ (Huey \& Mohr, 1981) has led us to consider DNA condensation as a unifying explanation for the acceleration of renaturation observed in the three systems described above (the excluded volume method, the catalysis by single-stranded DNA binding proteins and PERT). In particular, we have investigated the effect of increasing salt concentrations in PERT in order to demonstrate DNA condensation in this system.

This demonstration enables us to provide a basic answer to the question of the optimization of DNA renaturation: optimal conditions are not obtained with DNA molecules in solution but with condensed DNA molecules.

\section{(e) The biological significance of condensed DNA: the problem of the physical basis of genetic recombination}

From the biological point of view, the study of DNA condensation is of interest for two structural reasons: first, it is related to the problem of the packaging of DNA in a virus or a cell (for a recent review, see Yevdokimov et al., 1988); secondly, because the condensation of DNA can be coupled to an isotropic-liquid crystalline transition, this transition can lead to a self-organization of matter, establishing ordered patterns over large distances, comparable to cellular dimensions (Lerman \& Allen, 1974). This transition is therefore of interest for the problem of biological morphogenesis (Bouligand, 1985; for a review on morphogenesis, see Gierer, 1981), particularly in the case of the primitive stages of life, where nucleic acids are often supposed to be the major components of replicative organisms. 
In the present article we are interested by the functional properties of condensed DNA, in particular those that are related to the problem of the physical basis of genetic recombination. The enzymatic approach to the problem of genetic recombination has led to the characterization of protein RecA (reviewed by Radding, 1989). This protein is able to perform a strand exchange reaction in vitro; the reaction can be stimulated by single-stranded binding proteins such as Escherichia coli singlestranded DNA binding protein or the gene 32 protein of phage T4. $\Lambda$ s observed by Radding (1989), the physical basis for these actions of RecA has remained obscure.

The observation that protein RecA is also able (1) to accelerate the rate of $\mathrm{DNA}$ renaturation (Weinstock et al., 1979), and (2) to condense singlestranded and double-stranded DNA (the terms of aggregation and coaggregation are commonly used to describe DNA condensation by $\operatorname{RecA}$ : see Radding, 1989) has led us to hypothesize that the simultaneous condensation of single and doublestranded DNA molecules could suffice to permit strand exchange reactions. We describe here a strand exchange experiment performed without protein, which supports this hypothesis.

\section{Theory}

The DNA renaturation reaction can be separated into a rate-limiting nucleation event (characterized by a rate constant $k_{\text {nu }}$ ) that involves the formation of the first few base-pairs and a faster propagation reaction (the zippering reaction), which involves the base-pair formation to the end of the molecule (Wetmur, 1976). Here we study the renaturation of DNA molecules devoid of repeating sequences (which are therefore heteropolymers: the kinetics of renaturation of homopolymers differ by the multiplicity of the nucleation sites). Among the various variables that affect the nucleation rate, we shall consider two of them that are important for the present paper: the length (or degree of polymerization $N$ ) of the reacting complementary strands and the salt concentration.

\section{(a) Scaling considerations}

If we consider the renaturation of two complementary strands of size $N$, according to the description of the reaction given above, the rate constant $k_{2}$ is related to $k_{\mathrm{nu}}$ by the equation:

$$
k_{2}=k_{\mathrm{nu}} N \text {. }
$$

Using randomly sheared DNA, Wetmur \& Davidson (1968) have investigated the relationship between $k_{2}$ and $N$ for various sizes of reassociating strands and found that $k_{2}$ is proportional to the square root of $N$ $\left(k_{2} \sim N^{1 / 2}\right)$. This result implies a decreasing availability of nucleation sites with increasing $N$ $\left(k_{\mathrm{nu}} \sim N^{-1 / 2}\right)$ which they interpreted as the consequence of an excluded volume effect (the longer a
DNA strand, the more difficult it is for a second strand to interpenetrate and find complementary sites). To generalize the scaling law obtained by Wetmur \& Davidson (1968, eqns (24) to (28)), we consider two complementary strands of degree of polymerization $N$, with an identical root-meansquared end-to-end distance $R$, and which react in a $d$-dimensional system. We obtain:

$$
k_{\mathrm{nu}} \sim \frac{R^{d}}{N^{2}} \quad \text { and } \quad k_{2} \sim \frac{R^{d}}{N}
$$

This last relation predicts that the rate of renaturation is affected by the configuration of complementary strands. If we further hypothesize that $R$ follows a scaling law defined by a critical exponent $v$ $\left(R \sim N^{v}\right)$, we obtain the scaling law: $k_{2} \sim N^{v d^{-1}}$.

Two values of $v$ are of interest. The case $v=1 / 2$ corresponds to ideal (Gaussian) polymers (i.e. without excluded volume effects). We obtain:

$\begin{array}{ll}\text { for } d=3 & k_{2} \sim N^{(d / 2)-1}, \\ \text { and for } d=2 & k_{2} \sim N^{1 / 2}, \\ k_{2} \sim N^{0} .\end{array}$

These relationships are in agreement with the results obtained in three-dimensional systems (Wetmur \& Davidson, 1968; Hinnebusch et al., 1978) as well as in the putative two-dimensional system PERT (Kohne et al., 1977; Wieder \& Wetmur, 1982): in this case $k_{2}$ is known to be independent of $N$.

The case $v=1 / d$ corresponds to a complete $d$-dimensional collapse. We obtain $k_{2} \sim N^{0}$ for all values of $d$.

This relation predicts that $k_{2}$ is independent of $N$ for all dimensions. In the case $d=2$, this relation does not discriminate between an ideal and a collapsed polymer.

In the case $d=2$, another mechanism may also account for the relation $k_{2} \sim N^{0}$ : we may hypothesize (1) that in the phenol/water interface the denatured DNA molecules are aligned, extended stiff rods (in other words that the transition from $d=3$ to $d=2$ coincides with an isotropic to a nematic state transition), and (2) that the renaturation is a diffusion-controlled process. In this hypothesis, the nucleation constant $k_{\text {uu }}$ would be proportional to $D_{\mathrm{T}}$, the translational diffusion coefficient of each strand (see Wetmur \& Davidson, 1968, p. 364). Since for a fully extended polymer $D_{\mathrm{T}} \sim 1 / N$, this mechanism would also account for the relation $k_{2} \sim N^{0}$.

We also observe that the relation $k_{2} \sim\left(R^{d} / N\right)$ implies that $k_{2}$ should be affected by increasing DNA concentration (since $R$ is generally a function of polymer concentration: see de Gennes, 1985) or by salt concentration. At very low salt concentration, for instance, we expect the DNA molecules to be very stretched $(v>1 / 2): k_{2}$ should increase faster than $N^{1 / 2}$ (for $d=3$ ).

Finally, since $v$ cannot be smaller than $1 / d$, according to this model we should never observe a decrease of $k_{2}$ with $N$. 


\section{(b) Salt concentration effects on the renaturation rate}

We consider first denatured DNA molecules in solution: the effects of salt concentration on the rate of renaturation have been extensively studied experimentally (see Studier, 1969b) and are well understood in the theoretical framework developed by Manning for polyelectrolytes (Manning, 1978). The reaction is schematized as follows:

$$
A+A^{\prime} \leftrightarrows C_{0} \rightarrow \text { nucleation } \rightarrow \text { zipping, }
$$

where $\mathrm{A}$ and $\mathrm{A}^{\prime}$ are the separated complementary strands and $\mathrm{C}_{0}$ the non-bonded precursor to the nucleated form. The rate-limiting step is the preequilibrium between the separated strands and $\mathrm{C}_{0}$ (see Wetmur \& Davidson, 1968). The polyelectrolyte theory of counterion condensation indicates that the reaction in the pre-equilibrium is at the molecular level

$$
x \mathrm{Na}^{+}+\mathrm{A}+\mathrm{A}^{\prime} \leftrightarrows \mathrm{C}_{0} .
$$

The reaction rate $v$ is proportional to $C_{0}$; the relation between $v$ and the concentration of salt present derives from the law of mass action; we obtain a power law: $v \sim\left(a_{\mathrm{Na}^{+}}\right)^{x}$ (where $a_{\mathrm{Na}^{+}}$is the activity of the sodium ion); plotting the logarithm of $k_{2}$ versus the logarithm of salt concentration should give a straight line. This prediction is confirmed experimentally; Studier (1969b) has found a value of $x$ between 3 and 4 at low salt concentration $\left(10^{-2}\right.$ to $10^{-1} \mathrm{M}$ ) and 25 to $35^{\circ} \mathrm{C}$. The value of $x$ can be used to calculate the number of nucleotides aligned in an unbonded configuration in $C_{0}$ (Manning, 1978).

Now we consider the effect of salt concentration on the condensation of denatured DNA molecules. According to Manning's theory, the transition can occur when a critical fraction of the DNA phosphate charge has been neutralized by the counterions. Wilson \& Bloomfield (1979) have applied this theory to experimental results and suggested that, for double-stranded DNA molecules, the transition takes place when 89 to $90 \%$ of the phosphate charges have been neutralized. regardless of the chemical nature of the counterion. If the condensation of denatured DNA molecules affects the kinetics of renaturation, it is likely to be in a critical manner, which should not be compatible with a power law dependence. We ean therefore expeet that the investigation of salt concentration effects in a renaturation system where DNA condensation is plausible will enable us to discriminate between a reaction in solution and a reaction involving condensed denatured DNA.

\section{Materials and Methods}

\section{(a) Materials}

Restriction enzymes, T4 DNA polymerase and the Klenow fragment of DNA polymerase I were obtained from New England Biolabs. E. coli single-strand binding protein and RecA protein were from Pharmacia. Salmon sperm DNA was from Sigma; the other nucleic acids (HindIII cleaved $\lambda$ DNA, $(+)$ strands of $\phi \times 174$ and
M13mpl 8 and replicative forms I and II of $\phi X 174)$ were from New England Biolabs. Hexamminecobalt(III) $\left(\left(\mathrm{Co}\left(\mathrm{NH}_{3}\right)_{6}\right)^{3+}\right)$ was obtained from Fluka as the trichloride salt

\section{(b) Methods}

Standard methods were used in this article (see Ausubel et al. (1989) for references)

\section{(i) Renaturation studies}

$H$ indIIT cleaved $\lambda(\mathrm{c} / 857$ ind 1 Sam 7$)$ DNA $(2 \mu \mathrm{g})$ was 3 -end-labeled with either the Klenow fragment of DNA polymerase I or T4 DNA polymerase. Following the reaction, the DNA was purified by gel filtration on a Sephadex G-50 (Pharmacia) column equilibrated in $5 \mathrm{~mm}$-Tris $\cdot \mathrm{HCl}$ (pH 7.5) 1 mM-EDTA. DNA concentration was estimated from the u.v absorbance. The specific radioactivity obtained ranged between $10^{6}$ and $10^{7}$ cts $/$ min per $\mu \mathrm{g}$. Two methods were used to denature DNA: alkaline denatura tion consists of the incubation of 9 parts DNA solution at room temperature with 1 part $1 \mathrm{M}-\mathrm{NaOH}$ during 5 to $15 \mathrm{~min}$. The solution was neutralized with 5 parts $2 \mathrm{M}$-Tris $\mathrm{HCl}(\mathrm{pH} 4)$ (final $\mathrm{pH} \mathrm{8.5)}$. This tirst procedure introduces sodium ions, which can prevent DNA condensation in the presence of multivalent cations. To avoid this phenomenon, heat denaturation $\left(3 \mathrm{~min}\right.$ at $\left.95^{\circ} \mathrm{C}\right)$ was also emploved.

Renaturations were carried out by incubating the DNA material (usually $100 \mu \mathrm{l}$ placed in a $1.5 \mathrm{ml}$ Eppendorf tube) in a thermostated water bath set at the appropriate temperature. The desired renaturation temperature was obtained in less than $30 \mathrm{~s}$. Following the appropriate period of renaturation, a portion of the DNA material was pipetted and either kept on ice prior to loading or immediately loaded onto a gel and electrophoresed.

When sodium dextran sulfate $\left(M_{\mathrm{r}} 500,000\right.$, Fluka) was used in renaturation studies, the direct loading of the renaturation products was detrimental to the ensuing electrophoresis. Dextran sulfate was removed in the following way: the renaturation product was diluted with water to lower the dextran sulfate concentration below $12 \%(\mathrm{w} / \mathrm{v})$. An equal volume of a $0.7 \mathrm{~m}$ solution of $\mathrm{K}(\mathrm{l})$ was added, and the sample was kept on ice until a visible dextran sulfate precipitate appeared (these conditions were derived from Kimizuka et al., 1967). The precipitate was pelleted by centrifugation and the supernatant was removed for electrophoresis.

Agarose gel electrophoresis $(1 \%(w / v)$ gel in $1 \times$ Trisborate EDTA buffer) was used to analyze the products of the renaturation. Following completion of the electrophoresis. the gel was fixed in $10 \%(\mathrm{v} / \mathrm{v})$ acetic acid for $30 \mathrm{~min}$ at room temperature, dried onto DEAE paper (DE81. Whatman) and autoradiographed. To cuantify: the rate of renaturation, direct autoradiography (at roon temperature and without intensifying screens, except as noted) was used. The films were analyzed by densitometry scanning using autoradiograms in the linear dose-response zone of the film and a coupled-charge device camera (CCD)

\section{(ii) Strand-transfer assay}

We have used the strand-transfer assay developed by MeCarthy et al. (1988). The supercoiled replicative form (RFI) of $\phi \mathrm{X} 174$ DNA was digested with HpaII and 3 end-labeled with the Klenow fragment of DNA poly merase I or T4 DNA polymerase. The labeled material was purified by gel filtration on Sephadex $(-50)$ as above 
The recovered DNA was either used directly or concentrated on Centricon microconcentrators (Amicon) before use. Following the strand-transfer assays the samples were processed by gel electrophoresis and autoradiography as described above.

\section{Results}

\section{(a) Measurement of renaturation rates}

The agarose gel electrophoresis technique used in this paper is illustrated in Figure 2(a). The difference between migration rates allows discrimination between the native and denatured forms of the eight restriction fragments of the HindIII digest of $\lambda$ DNA. The identification of the denatured species (based on the relative migration and on the intensity) is shown for five of the restriction fragments $(125,564,2027,2322$ and 4361 base-pair fragments).

Let $C_{0}$ be the molar concentration of a doublestranded DNA fragment (assuming a molecular mass of $31.5 \times 10^{6}$ daltons for $\lambda$ DNA, a concentration of $1 \mu \mathrm{g} / \mathrm{ml}$ represents a concentration of $31.7 \mathrm{pm}$ for each of the restriction fragments).

The second-order rate constant $k_{2}$ can be obtained from a reciprocal second-order plot: calling $f_{\text {ss }}$ the fraction of DNA in single-stranded configuration at time $t$ :

$$
\frac{1}{f_{\mathrm{ss}}}=k_{2} C_{0} t+1
$$

$k_{2}$ can therefore be deduced from the slope of the straight line obtained in this reciprocal plot (note: $k_{2}$ is often expressed using the total phosphate concentration $P_{\mathrm{T}}$ rather than the molar concentration; in this case a different value of $k_{2}$ is obtained). Such a determination is shown in Figure 2(b): the fractions of the $\mathbf{5 6 4} \mathrm{bp}$ fragment in single-stranded and double-stranded configuration have been obtained from Figure $2(\mathrm{a})$. The corresponding value for $k_{2}$ is $2.6 \times 10^{7} \mathrm{~m}^{-1} \mathrm{~s}^{-1}$. The values obtained for the five smallest restriction fragments (125, 564, 2027, 2322 and 4361 base-pairs) are shown in Figure 2 (c). In this double logarithmic plot the relationship between $\log k_{2}$ and $\log N$ is approximately lincar: the straight line drawn in Figure 2(c) has a slope of 0.40 , corresponding to the scaling relation $k_{2} \sim$ $N^{0 \cdot 40}$.

\section{(b) Acceleration of the renaturation rates}

In this section we deseribe various means to accelerate renaturation in aqueous buffers.

\section{(i) Effect of poly(ethylene oxide) and sodium dextran sulfate}

Figure 3(a) illustrates the consequences of the addition of PEO (average $M_{\mathrm{r}} 8000$, Sigma) on DNA renaturation. We observe (1) the presence of aggregates at the top of the gel; (2) the disappearance of DNA fragments with a size superior to $4 \mathrm{~kb}$ in the gel; (3) a 100-fold acceleration of the renaturation of the 564 nucleotides fragment (Table 1); this accel- eration is consistent with the qualitative observations of Amasino (1986). The rate of the renaturation of the 125-nucleotide fragment is roughly ten times slower than that of the 564nucleotide fragment (Table 1), while the rate of the renaturation of the $2322 \mathrm{bp}$ fragment appears similar.

A small but detectable renaturation of the 564nucleotide fragment takes place at room temperature (see lane 0 in Fig. $3(a)$ ). The rate of renaturation of this fragment at $37^{\circ} \mathrm{C}$ in the presence of $15 \%$ $\mathrm{PEO}$ is greater than the rate obtained in standard conditions (see Table 1).

Figure 3(b) illustrates the consequences of the addition of sodium dextran sulfate (abbreviated DS) on DNA renaturation. We observe (1) the presence of aggregates at the top of the gel; (2) a decrease in the amount of DNA fragments with a size greater than $4 \mathrm{~kb}$ in the gel; (3) a 50 -fold acceleration of the renaturation of the 564-nucleotide fragment (see Fig. 3(c) and Table 1). Very little acceleration (if any) of the renaturation of the $125 \mathrm{bp}$ fragment is observed (as a rough estimate, the renaturation rate was considered as unchanged in Table 1); and the rate of the renaturation of the 2322 -nucleotide fragment is clearly slower than that of the 564 nucleotide fragment.

We have followed the renaturation kineties for various concentrations of $\mathrm{PEO}$ and $\mathrm{DS}$ ranging from 5 to $40 \%(\mathrm{w} / \mathrm{v})$ (Fig. $3(\mathrm{c}))$. The $17.5 \%(\mathrm{w} / \mathrm{v})$ concentration used in Figure 3(a) and (b) corresponds to the optimal acceleration of the renaturation of the 564-nucleotide fragment; the logarithm of the rate constant for this fragment is proportional to the polymer (PEO or DS) concentration between 5 and $17 \cdot 5 \%$. In the case of the $125 \mathrm{bp}$ fragment, optimal conditions are obtained for higher polymer concentration (about $35 \%$ ). In addition, in the presence of $35 \%$ DS, the addition of heterologous I)NA (at $250 \mu \mathrm{g} / \mathrm{ml}$ ) can further accelerate the renaturation of this fragment by excluded volume effects (see Table 1). In these conditions there is a large decrease of the amount of the $564 \mathrm{bp}$ fragment in the gel. The results obtained in these conditions are similar to those of Wieder \& Wetmur (1981): using such high DNA concentrations $(250 \mu \mathrm{g}$ and $1000 \mu \mathrm{g} / \mathrm{ml}$ ) and DNA fragments with an average size probably closer to 125 nucleotides rather than 564 nucleotides, they obtained a 100 -fold acceleration, and the greatest acceleration was obtained for a DS concentration of about $35 \%$.

At PEO concentrations between 25 and $30 \%$, the renaturation of the 125-nucleotide fragment is faster than that of the 564-nucleotide fragment. (The values corresponding to $30 \% \mathrm{PEO}$ are given in Table 1.) As observed in the theoretical section, this result cannot be explained by the proposed scaling law.

\section{(ii) Effect of divalent cations}

Figure $3(\mathrm{~d})$ illustrates a renaturation carried out at $68^{\circ} \mathrm{C}$ in the presence of $50 \mathrm{~mm}-\mathrm{MgCl}_{2}$ (under 
DNA concentration: $|\mu \mathrm{g} / \mathrm{m}| / 68^{\circ} \mathrm{C} / \mid \mathrm{M}-\mathrm{NaCl}$

N

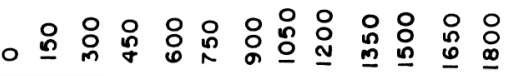

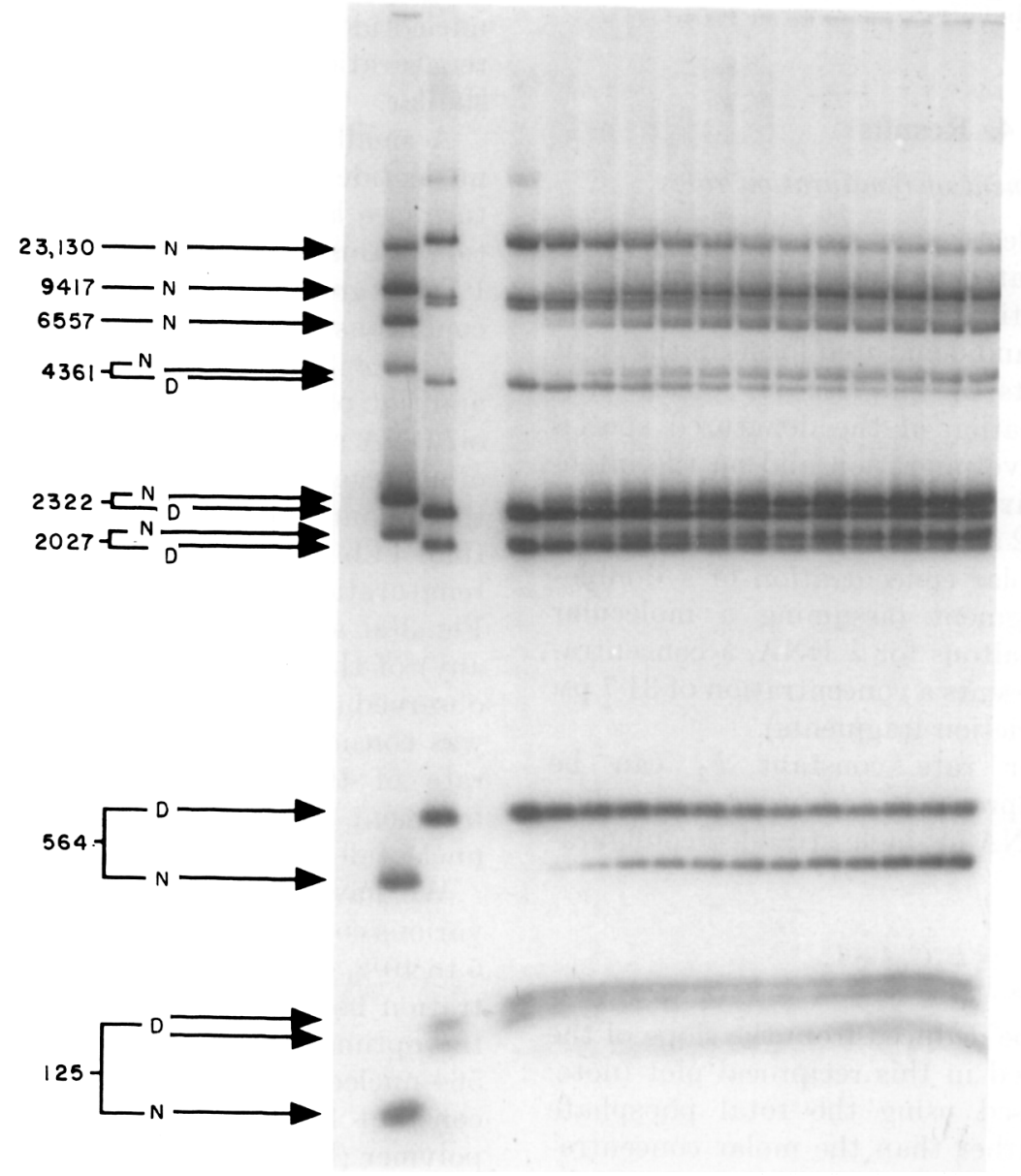

(a)

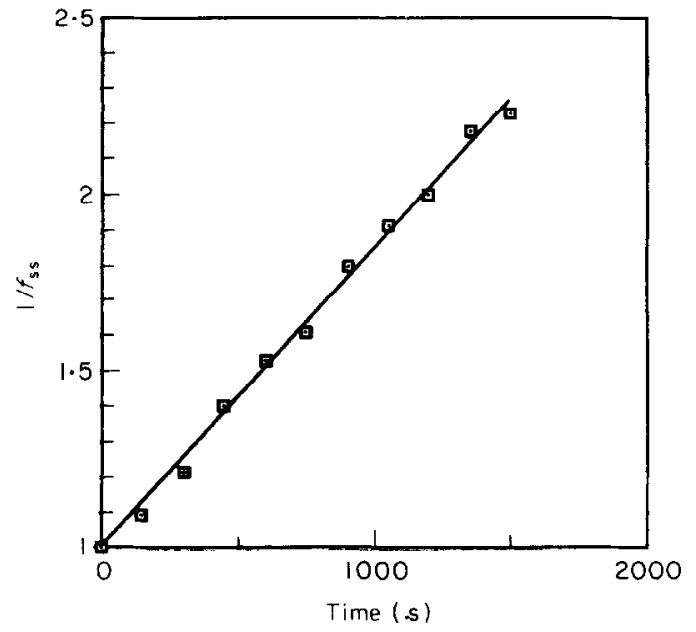

(b)

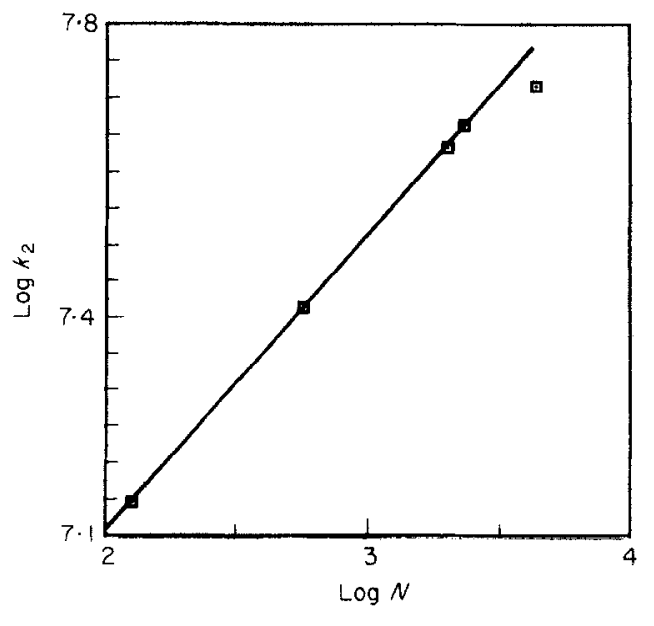

(c)

Figure 2. (a) Renaturation kineties of HindIII-cleaved $\lambda$ DNA (conen $1 \mu \mathrm{g} / \mathrm{ml})$ carried out at $68^{\circ} \mathrm{O}$ in $1 \mathrm{~m}-\mathrm{NaCl}$. Lane N, native DNA; lane D, alkali-denatured DNA; following lanes, renaturation of the alkali-denatured DNA. The incubation time at $68^{\circ} \mathrm{C}$ is indicated (in s) above each lane. (b) Reciprocal 2nd-order rate plot for the 564-nucleotide fragment. Data derived from the experiment of (a). (c) Correlation between $k_{2}$ and the length $N$ for 5 restriction fragments (125, 564, 2027, 2322 and 4361 base-pair fragments). Data derived from the experiment of (a), double logarithmic plot. The slope of the straight line drawn in this Figure is $\mathbf{0 \cdot 4 0}$. 
DNA concentration: $100 \mathrm{ng} / \mathrm{ml}$ $68^{\circ} \mathrm{C}$

DNA concentration: $50 \mathrm{ng} / \mathrm{ml}$ $68^{\circ} \mathrm{C}$

IM- $\mathrm{NaCl} / 17.5 \%(\mathrm{w} / v) \mathrm{DS}$

$1 \mathrm{M}-\mathrm{NaCl} / 17.5 \%(\mathrm{w} / v)$ PEO

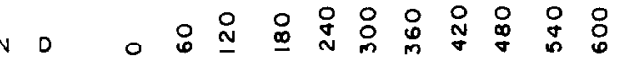

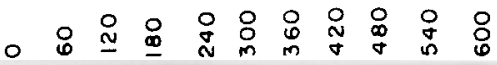

(a)

(b)

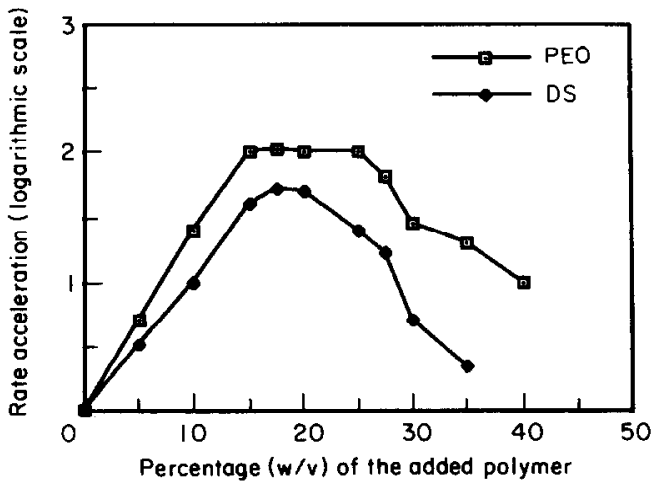

(c)

Fig. 3. 
NA concentration:

$50 \mathrm{ng} / \mathrm{ml}, 68^{\circ} \mathrm{C}$

$50 \mathrm{mM}-\mathrm{MgCl}_{2}$

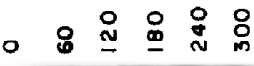

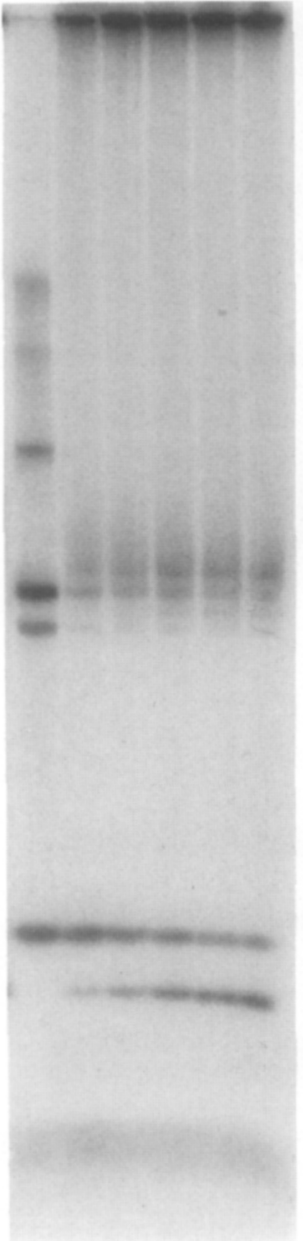

(d)
DNA concentration:

$50 \mathrm{ng} / \mathrm{ml}, 37^{\circ} \mathrm{C}$

$2 \mathrm{~mm}$-Co(III)

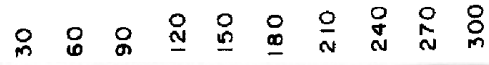

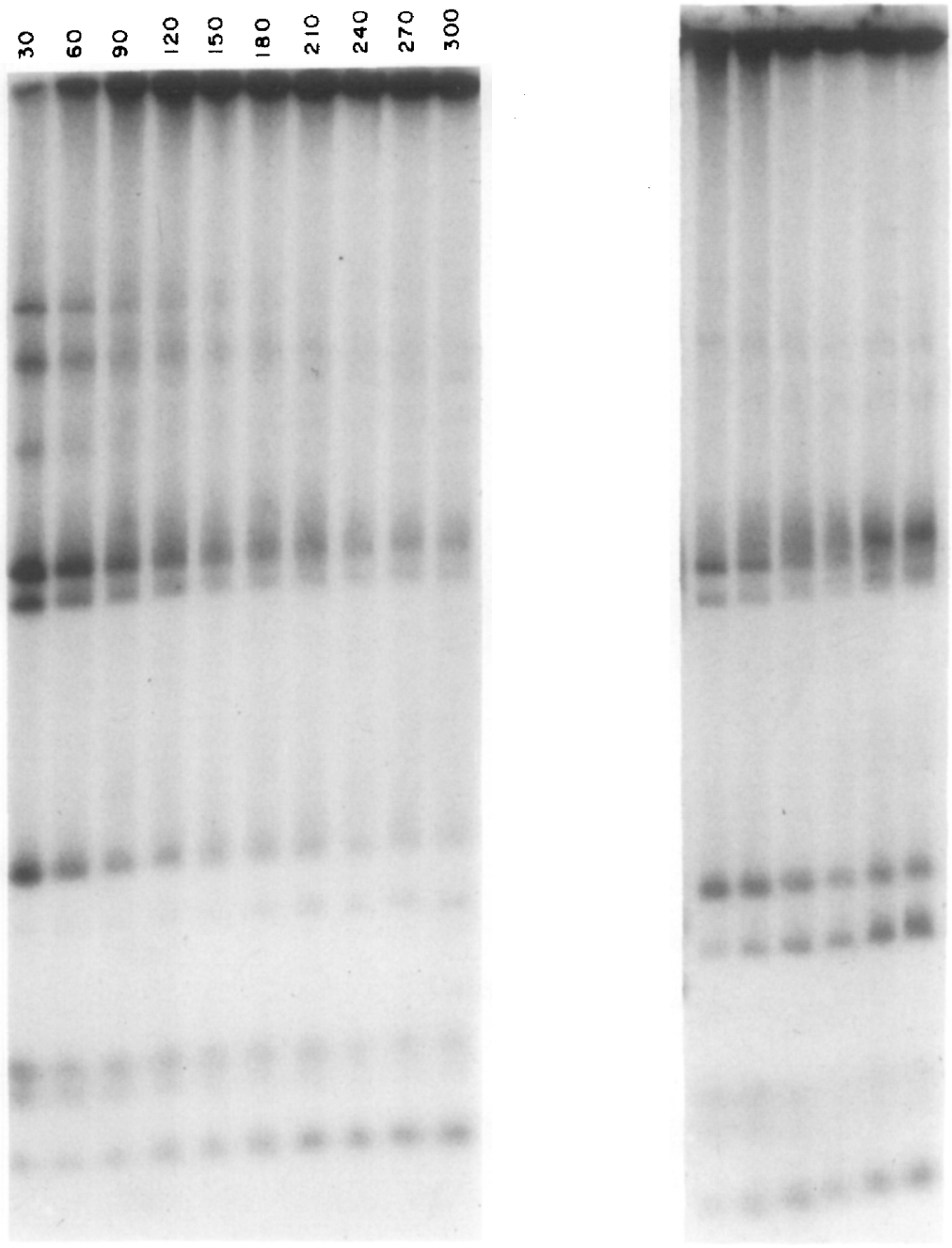

f)

g)

$2 \mathrm{~mm}-\mathrm{Cok}$ (II)

인

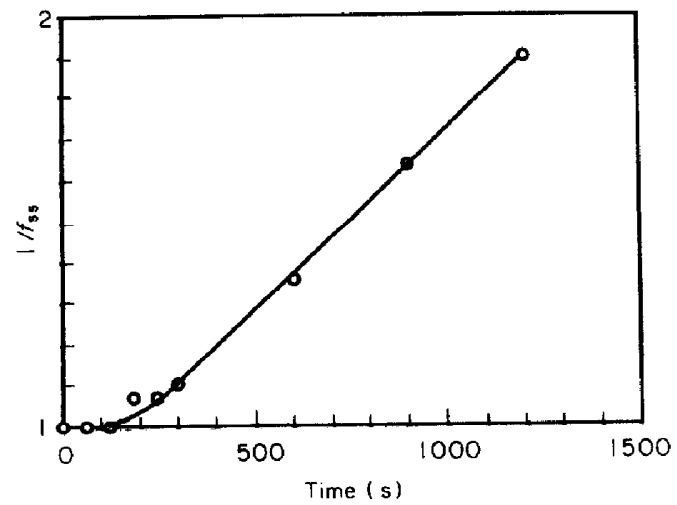

$50 \mathrm{ng} / \mathrm{mi}, 73^{\circ} \mathrm{C}$

(e)

Fig. 3. 


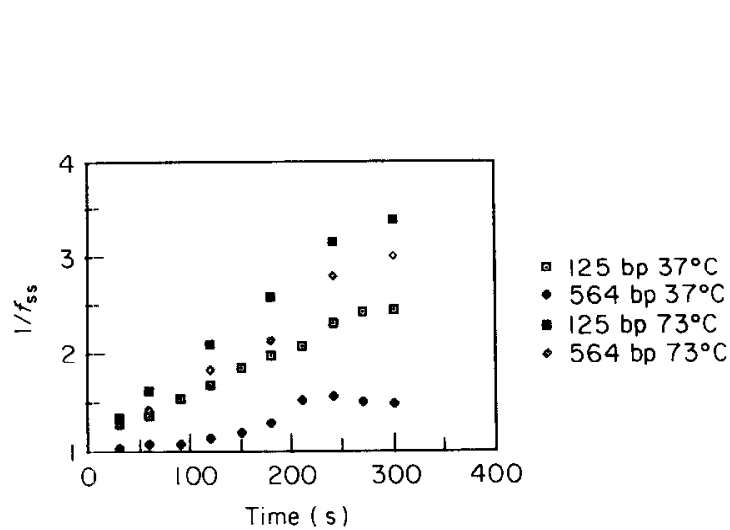

(h)

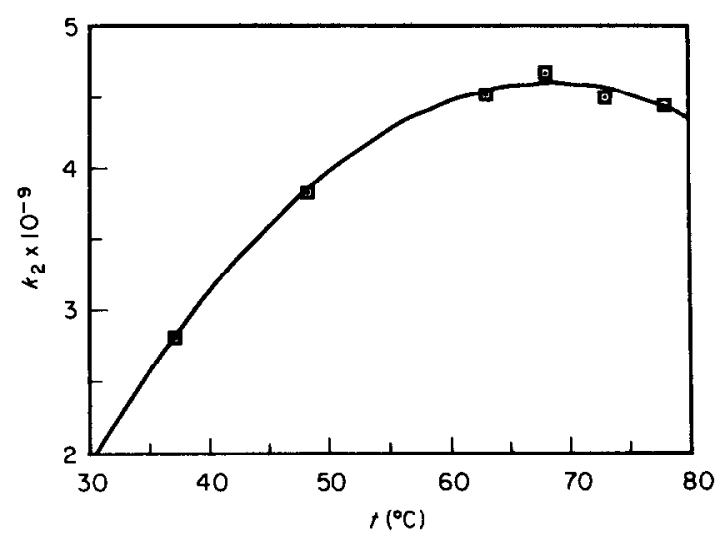

(i)

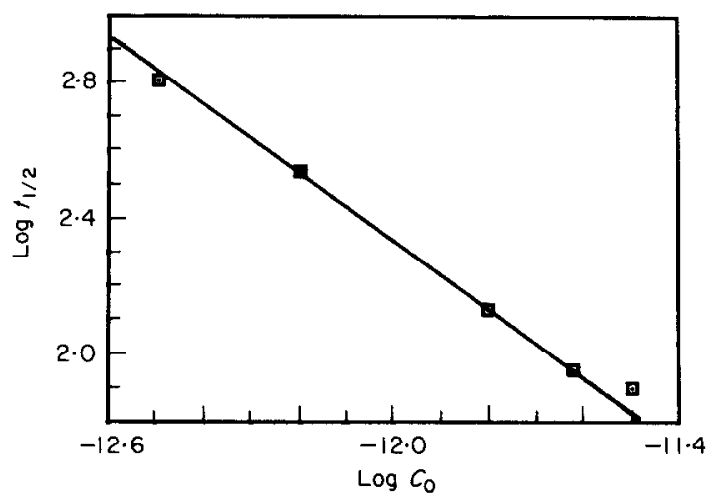

(j)

Figure 3. (a) Renaturation kineties of HindIII-cleaved $\lambda$ DNA (conen $50 \mathrm{ng} / \mathrm{ml}$ ) carried out at $68^{\circ} \mathrm{C}$ in $1 \mathrm{M}-\mathrm{NaCl}$, $17.5 \%$ PFO. Incubation times are indicated above each lane. (b) Renaturation kinetics of HindIII-cleaved $\lambda$ DNA (concn $100 \mathrm{ng} / \mathrm{ml}$ ) carried out at $68^{\circ} \mathrm{C}$ in $1 \mathrm{M}-\mathrm{NaCl}, 17.5 \% \mathrm{DS}$. Incubation times are indicated above each lane. Lane $\mathrm{N}$, native DNA; lane D, denatured DNA. (c) Effects of various concentrations of polymers (sodium dextran sulfate (DS or $\mathrm{PEO}$ ) on the kinetics of renaturation of the 564-nucleotide fragment in $1 \mathrm{~m}-\mathrm{NaCl}$ at $68^{\circ} \mathrm{C}$. The rate of acceleration (compared to the rate obtained in the absence of added polymer) was derived from the comparison of the half-times for renaturation. The DNA concentrations used were $50 \mathrm{ng} / \mathrm{ml}$ for PEO concentration ranging between 15 and $25 \%$, and $100 \mathrm{ng} / \mathrm{ml}$ otherwise. (d) Renaturation kinetics of heat-denatured HindIII-cleaved $\lambda$ DNA (conen $50 \mathrm{ng} / \mathrm{ml}$ ) carried out at $68^{\circ} \mathrm{C}$ in $50 \mathrm{~mm}-\mathrm{MgCl}_{2}$. Incubation times are indicated above each lane. (e) Renaturation kinetics (2nd-order rate plot) for heat-denatured $H$ indIII-cleaved $\lambda$ DNA $(50 \mathrm{ng} / \mathrm{ml})$ at $60^{\circ} \mathrm{C}$ in $50 \mathrm{~mm}-\mathrm{MgCl}_{2}$. Data for the 564-nucleotide fragment. (f) and (g) Renaturation kinetics of heat-denatured HindIII-cleaved $\lambda$ DNA $(50 \mathrm{ng} / \mathrm{ml})$ in the presence of 2 mm-hexamminecobalt(III) ((f) $37^{\circ} \mathrm{C}$; (g) $73^{\circ} \mathrm{C}$ ). Incubation times are indicated above each lane. (h) 2 nd-order rate plots for the 564 and 125-nucleotide fragments. Data from (f) and (g). (i) Temperature dependence of the reaction rate $k_{2}$ for the 125-nucleotide fragment ( $\lambda$ DNA conen $50 \mathrm{ng} / \mathrm{ml}$ ) in the presence of 2 mu-hexamminecobalt(III). (j) Concentration dependence of the reaction rate $k_{2}$ for the 125 -nucleotide fragment at $68^{\circ} \mathrm{C}$ in the presence of $2 \mathrm{~mm}$-hexamminecobalt(III). In these experiments, a constant rate of $\sim 4.7 \times 10^{9} \mathrm{M}^{-1} \mathrm{~s}^{-1}$ was obtained. This Figure shows that the half-time of the reaction is inversely proportional to the molar concentration $C_{0}$ of $\lambda$ DNA (the slope of the straight line drawn in this Figure is - 1 .

conditions derived from Knoll et al., 1986). Again, we observe the formation of aggregates, the disappearance of the larger DNA fragments in the gel and the acceleration of the renaturation of the 564 nucleotide fragment (see Table 1). The 125nucleotide fragment shows no detectable renaturation. A striking feature of the reaction is the existence of a small but significant lag in the kinetics; this lag is more clearly demonstrated when the reaction takes place at $60^{\circ} \mathrm{C}$ (Fig. 3(e)). A progressive appearance of the aggregates occurs during this lag; we found no detectable renaturation of the 125 nucleotide fragment at $60^{\circ} \mathrm{C}$ (data not shown). It is clear from these experiments that the renaturation of the 564-nucleotide fragment does not fully follow second-order kinetics: the rate constant derived from the slope of the straight line drawn in Figure $3(\mathrm{e})$ only defines an apparent rate constant, equal to $6.2 \times 10^{8} \mathrm{M}^{-1} \mathrm{~s}^{-1}$.

\section{(iii) Effect of trivalent cations}

In the experiments described here, denatured DNA was preincubated for one minute at the desired temperature, prior to the addition of hexamminecobalt(III). We have observed (data not shown) that additional renaturation takes place 
Table 1

Rates of renaturation for the 546 and the 125 bp fragments

\begin{tabular}{|c|c|c|c|c|}
\hline $\begin{array}{l}\lambda \mathrm{DNA} \\
\text { concentration }\end{array}$ & Reaction medium & $\begin{array}{l}\text { Temperature } \\
\left({ }^{\circ} \mathrm{C}\right)\end{array}$ & $\begin{array}{l}k_{2 \mathrm{app}} \times 10^{-7} \\
\left(\mathrm{M}^{-1} \mathrm{~s}^{-1}\right)\end{array}$ & $R_{\dagger}^{\dagger}$ \\
\hline $1 \mu \mathrm{g} / \mathrm{ml}$ & $1 \mathrm{M}-\mathrm{NaCl}$ & 68 & $\begin{array}{c}2 \cdot 6 \\
1 \cdot 4(125 \mathrm{hp})\end{array}$ & 1 \\
\hline $50 \mathrm{ng} / \mathrm{ml}$ & $\begin{array}{l}1 \mathrm{M}-\mathrm{NaCl} \\
17.5 \% \mathrm{PEO}\end{array}$ & 68 & $\begin{array}{c}240 \\
23(125 \mathrm{bp})\end{array}$ & 93 \\
\hline $100 \mathrm{ng} / \mathrm{ml}$ & $\begin{array}{l}1 \mathrm{~m}-\mathrm{NaCl} \\
30 \% \mathrm{PEO}\end{array}$ & 68 & $\begin{array}{c}74 \\
180(125 \mathrm{bp})\end{array}$ & 29 \\
\hline $100 \mathrm{ng} / \mathrm{ml}$ & $\begin{array}{l}1 \mathrm{M}-\mathrm{NaCl} \\
17.5 \% \mathrm{DS}\end{array}$ & 68 & $\begin{array}{c}140 \\
-1.4(125 \mathrm{bp})\end{array}$ & 54 \\
\hline $100 \mathrm{ng} / \mathrm{ml}$ & $\begin{array}{l}1 \mathrm{M}-\mathrm{NaCl}, 35 \% \text { DS, } 250 \mu \mathrm{g} \\
\quad \text { sss DNA } / \mathrm{ml} \ddagger\end{array}$ & 68 & $210(125 b p)$ & \\
\hline $50 \mathrm{ng} / \mathrm{ml}$ & $50 \mathrm{mM}-\mathrm{MgCl}_{2}$ & 68 & 350 & 133 \\
\hline $50 \mathrm{ng} / \mathrm{ml}$ & $50 \mathrm{~mm}-\mathrm{CoIII}$ & 68 & $470(125 \mathrm{bp})$ & \\
\hline $100 \mu \mathrm{g} / \mathrm{ml}$ & $\mathrm{l} \mathrm{M}-\mathrm{NaCl}$ & 37 & $1.4 \times 10^{-\frac{1}{2}}$ & $6 \times 10^{-3}$ \\
\hline $500 \mathrm{ng} / \mathrm{ml}$ & $1 \mathrm{M}-\mathrm{NaCl}, 17.5 \% \mathrm{PEO}$ & 37 & $6 \%$ & $2 \cdot 6$ \\
\hline $50 \mathrm{ng} / \mathrm{ml}$ & $2 \mathrm{~mm}-\mathrm{CoIII} \S$ & 37 & 280 & $(125 \mathrm{bp})$ \\
\hline $100 \mathrm{ng} / \mathrm{ml}$ & $\begin{array}{l}2 \mathrm{~m}-\mathrm{NaCl}, 35 \% \text { ethanol, } 100 \mu \mathrm{g} \\
\text { sss } \mathrm{DNA} / \mathrm{ml}\end{array}$ & 37 & 11 & 4 \\
\hline
\end{tabular}

$\dagger R$ is the rate acceleration compared to the rate in $1 \mathrm{~m}-\mathrm{NaCl}, 68^{\circ} \mathrm{C}$ for the $564 \mathrm{bp}$ fragment (the unspecified rate constants refer to the $564 \mathrm{bp}$ fragment).

$\ddagger$ sss DNA, abbreviation for sonicated salmon sperm DNA

$\$$ CoIII, abbreviation for hexamminecobalt(III).

if the reaction products are not loaded and electrophoresed immediately (even if the reaction products are refrigerated at $0^{\circ} \mathrm{C}$ prior to loading). For this reason, the reaction products were loaded and electrophoresed immediately after renaturation.

Figure $3(\mathrm{f})$ and $(\mathrm{g})$ illustrates renaturations carried out at two temperatures $\left(37^{\circ} \mathrm{C}\right.$ and $\left.73^{\circ} \mathrm{C}\right)$ in the presence of millimolar concentrations of hexamminecobalt(III).

We observe again the formation of aggregates, the disappearance of the larger DNA fragments in the gel and the acceleration of the renaturation of the 564 and the 125-nucleotide fragments. In addition, it is clear that at $37^{\circ} \mathrm{C}$ (but not at $73^{\circ} \mathrm{C}$ ) the amount of DNA found in the gel for the 564nucleotide fragment is much less than the total amount present at the beginning of the renaturation.

The reciprocal second-order plots corresponding to the renaturation of the 125 and the 564nucleotide fragments are given in Figure $3(\mathrm{~h})$. The reaction rates (see Table 1) are clearly greater for the smaller fragment (in the case of the 564nucleotide fragment at $37^{\circ} \mathrm{C}$, since only a small fraction of the input DNA is analyzed, the signifieance of the apparent rate is unclear).

The effect of the temperature on the renaturation rate of the 125-nucleotide fragment is shown in Figure 3(i).

A bell-shaped dependence is observed with a maximum rate of $4.7 \times 10^{9} \mathrm{M}^{-1} \mathrm{~s}^{-1}$ at $68^{\circ} \mathrm{C}$. In contrast with the results obtained in the presence of $\mathrm{NaCl}$ (see Studier, 1969b), however, there is less than a twofold variation in the renaturation rates between $37^{\circ} \mathrm{C}$ and $78^{\circ} \mathrm{C}$. At high temperatures $\left(73^{\circ} \mathrm{C}\right.$ and $\left.78^{\circ} \mathrm{C}\right)$, the renaturation rates of the 564 nucleotide fragment $\left(3.7 \times 10^{9} \mathrm{M}^{-1} \mathrm{~s}^{-1}\right.$ at $73^{\circ} \mathrm{C}$ and
$3.8 \times 10^{9} \mathrm{M}^{-1} \mathrm{~s}^{-1}$ at $\left.78^{\circ} \mathrm{C}\right)$ and the $125-$ nucleotide fragment $\left(4.5 \times 10^{9} \mathrm{M}^{-1} \mathrm{~s}^{-1}\right.$ at $73^{\circ} \mathrm{C}$ and $4.4 \times 10^{9} \mathrm{M}^{-1} \mathrm{~s}^{-1}$ at $78^{\circ} \mathrm{C}$ ) are very close

We have also investigated the effect of various DNA concentrations on the renaturation rate of the 125-nucleotide fragment at $68^{\circ} \mathrm{C}$ (Fig. 3(j); at low concentrations autoradiography was performed with preflashed films and intensifying screens at $-70^{\circ} \mathrm{C}$ ). The rate constant in these experiments is independent of the concentration, which confirms that the reaction follows second-order kinetics.

\section{(c) Salt concentration effects on renaturation rates}

In this section we investigate the effects of various salt concentrations on the rates of renaturation in order to clarify the mechanism of the reaction.

\section{(i) Effects of trivalent cations}

Figure 4(a) shows the effects of increasing hexamminecobalt(III) concentrations on the renaluration of denatured DNA. We observe (1) the appearance of aggregates between 200 and $400 \mu \mathrm{M}$; (2) this appearance correlates with the disappearance of DNA fragment larger than $2 \mathrm{~kb}$ from the gel, as well as a marked reduction of the amount of the 564-nucleotide fragment in the gel; and (3) this appearance correlates with the renaturation of both the 125 and 564 nucleotide fragments. The renaturation of the 125-nucleotide fragment has been quantified in Figure 4(b); it is clear that in this double logarithmic plot, the curve obtained cannot be fit with a straight line, this rules out a power-lawtype relationship between the rate constant and the salt concentration. 
DNA concentration: $100 \mathrm{ng} / \mathrm{m}$ /

15 minutes at $37^{\circ} \mathrm{C}$

Co(III) concentration in $\mu \mathrm{M}$

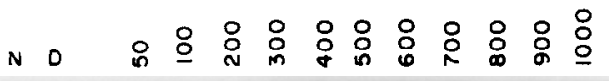

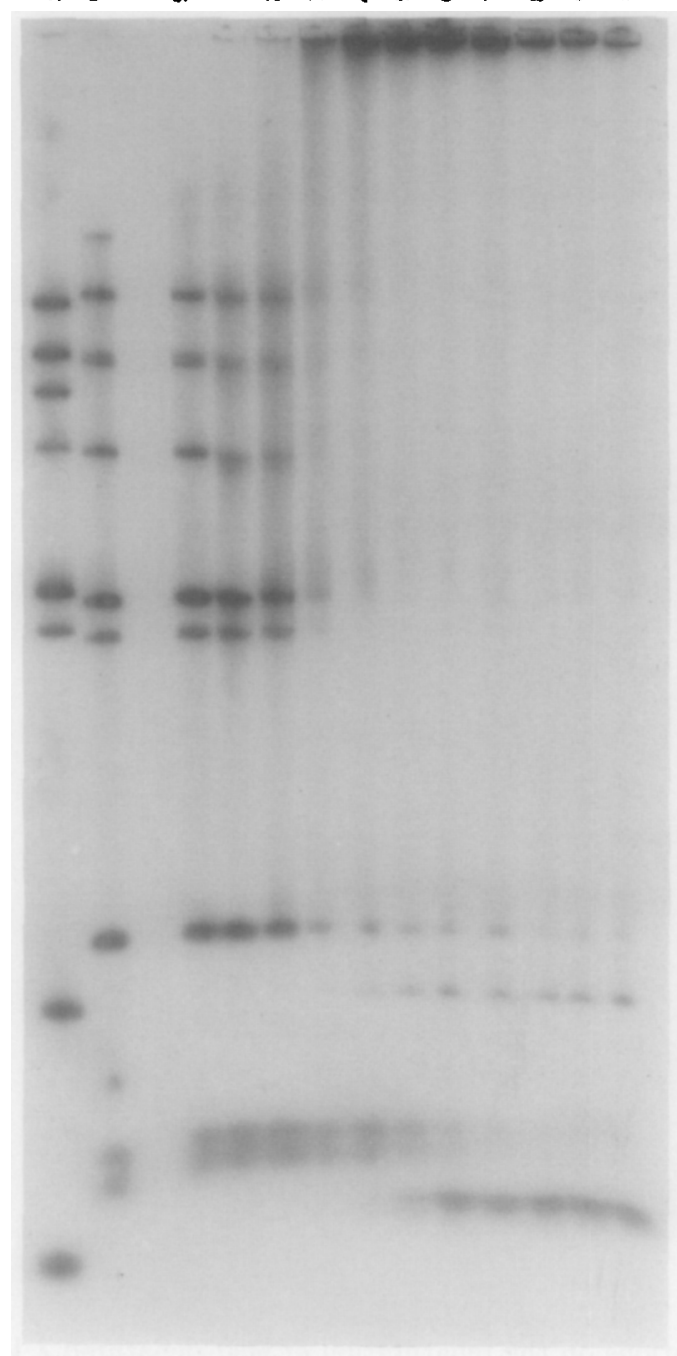

(a)
DNA concentration: $50 \mathrm{ng} / \mathrm{ml}$

PERT during 20 seconds

$\mathrm{NaCl}$ concentration in $\mathrm{mM}$

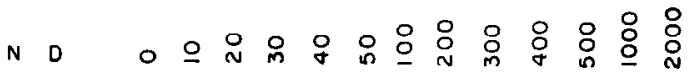

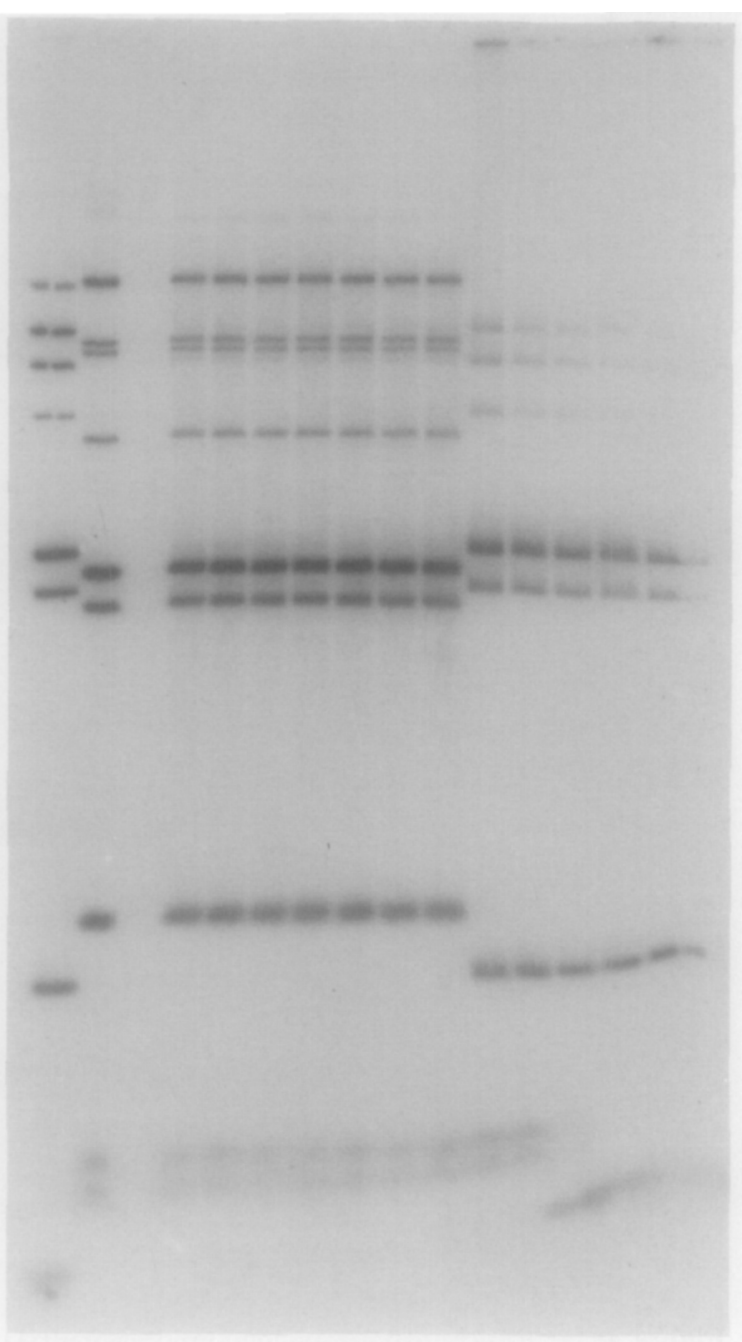

(c)

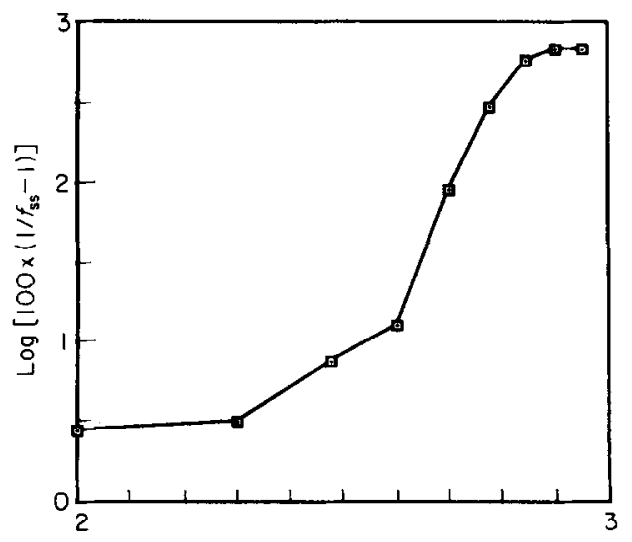

Hexamminecobalt (III) concentration in $\mu \mathrm{m}$ logarithmic scale

(b)

Fig. 4 


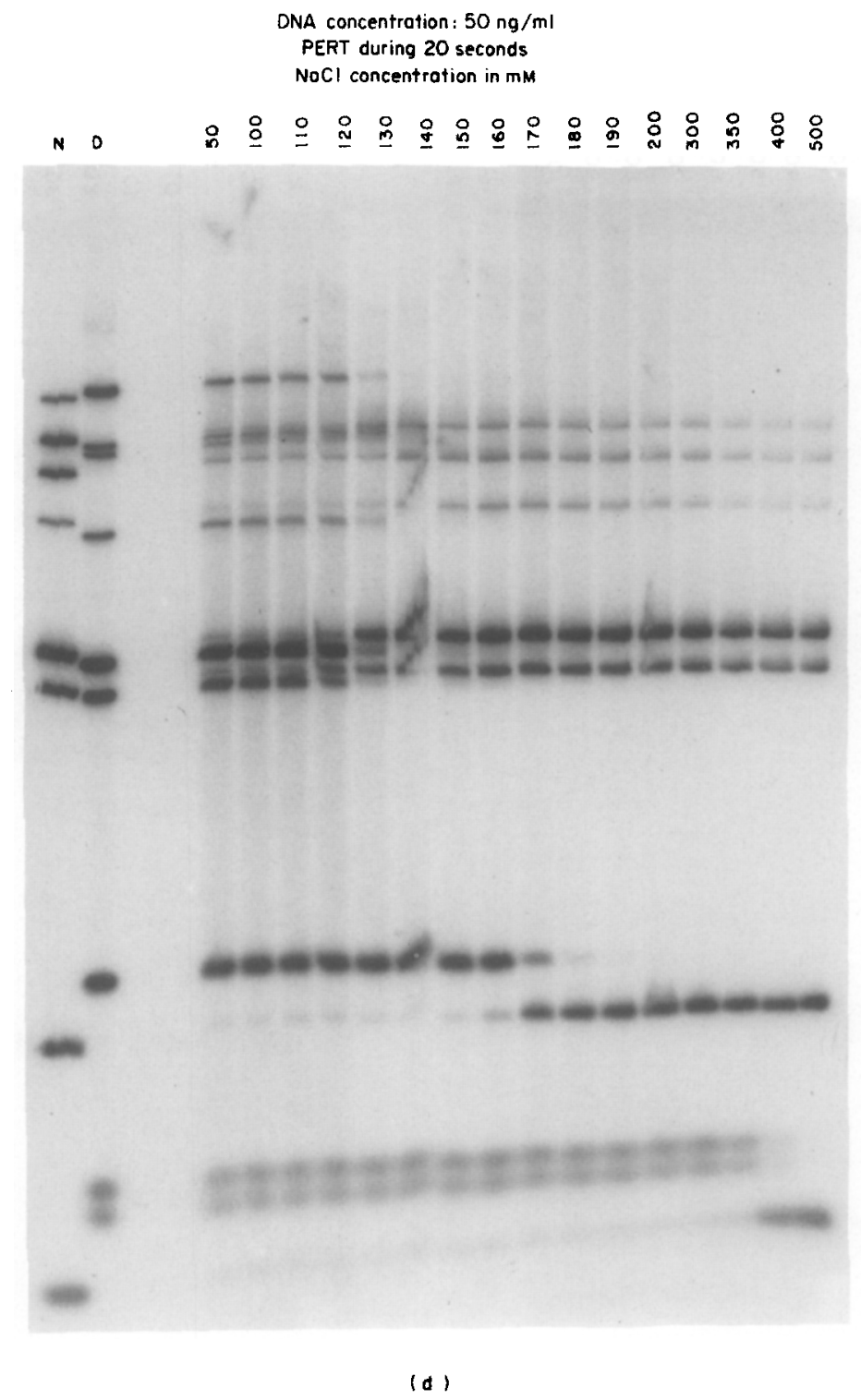

Figure 4. (a) Effects of various hexamminecobalt(III) concentrations on the renaturation of heat-denatured $\hat{\lambda}$ DNA $(100 \mathrm{ng} / \mathrm{ml})$ at $37^{\circ} \mathrm{C}$. Lane $\mathrm{N}$, native DNA; lane D, heat-denatured DNA; following lanes common incubation of $15 \mathrm{~min}$. The salt concentration (in $\mu \mathrm{M}$ ) is indicated above each lane. (b) Quantification of the renaturation of the 125-nucleotide fragment as a function of the hexamminecobalt(III) concentration. Data from (a). Double logarithmic plot. (c) and (d) Effects of various $\mathrm{NaCl}$ concentrations on the renaturation of heat-denatured $\lambda \mathrm{DNA}(50 \mathrm{ng} / \mathrm{ml})$ at room temperature in the PERT system. Eppendorf tubes containing $80 \mu \mathrm{l}$ of denatured DN $\Lambda$ and salt plus $20 \mu \mathrm{l}$ of $90 \%$ phenol (added last) were shaken for $20 \mathrm{~s}$ and left to stand for several minutes. Portions of the aqueous phases were analyzed by gel electrophoresis. The use of $18 \%$ phenol guarantees the presence of an emulsion even at very low salt concentrations. Lanes $\mathrm{N}$. native DNA; lanes $\mathrm{D}$. heat-denatured DNA. NaCl concentrations (in $\mathrm{mm}$ ) are indicated above each lane

\section{(ii) Effects of $\mathrm{NaCl}$ in the phenol emulsion reassociation technique.}

Figure 4(c) shows the effects of increasing $\mathrm{NaCl}$ concentration on PERT. A clear-cut transition occurs between 100 and $200 \mathrm{~mm}$ : very little reassociation can be detected below $100 \mathrm{~mm}$ and, except for the $125 \mathrm{bp}$ fragment, the renaturation is essentially complete above $200 \mathrm{~mm}$. The renaturation of the $125 \mathrm{bp}$ occurs only at higher concentrations (between $300 \mathrm{~mm}$ and $500 \mathrm{~mm}$ ). A refinement of Figure $4(\mathrm{c})$ is displayed in Figure $4(\mathrm{~d})$. Using $10 \mathrm{~mm}$ increments of the $\mathrm{NaCl}$ concentration between 100 and $200 \mathrm{~mm}$ makes it possible to define the transitions more accurately. DNA fragments larger than $2 \mathrm{~kb}$ undergo the transition between 110 and $150 \mathrm{~mm}$. The transition takes place between 150 and $190 \mathrm{~mm}$ for the 564-nucleotide fragment. Again, the salt dependence observed is clearly incompatible with a power-law-type relationship between the rate constant and the salt concentration. To rule out the possibility that these transitions result from a change of the melting temperature we performed the following experiments: Eppendorf tubes containing $50 \mathrm{ng}$ of native $\mathrm{DNA} / \mathrm{ml}$ and otherwise components identical to those deseribed in Figure 4 
(i.e. $20 \%$ phenol and various concentrations of $\mathrm{NaCl})$ were incubated either at room temperature or at $37^{\circ} \mathrm{C}$ for ten minutes, vortexed for 20 seconds at the same temperature and further kept ten minutes at this temperature. Portions of the aqueous phases were analyzed by electrophoresis; we did not observe any denaturation in these experiments (data not shown).

\section{(d) Ethanol and salt accelerated renaturation}

$\Lambda$ bove critical concentrations of cthanol and salt, a DNA condensation occurs, which can be monitored by circular dichroism (Huey \& Mohr, 1981). At constant $35 \%(\mathrm{v} / \mathrm{v})$ ethanol concentration, increasing $\mathrm{NaCl}$ concentration generates first a $\psi(+)$ form (a condensed form with a positive ellipticity), which is converted by further $\mathrm{NaCl}$ increase into a $\psi(-)$ form (with a large negative ellipticity) via a series of intermediate forms (see Fig. 6 of Huey $\&$ Mohr, 198I). Figure 5(a) shows the effects of increasing $\mathrm{NaCl}$ concentrations at $37^{\circ} \mathrm{C}$ in a medium containing (1) $35 \%(\mathrm{v} / \mathrm{v})$ ethanol concentrations and (2) double-stranded sonicated salmon sperm DNA (conce $100 \mu \mathrm{g} / \mathrm{ml}$ ) in addition to $\lambda \mathrm{DNA}$. We observe (1) the appearance of aggregates for $\mathrm{NaCl}$ concentrations higher than $1.2 \mathrm{M} ;(2)$ an increase of the rate of renaturation of the 564-nucleotide fragment between $0 \cdot 2$ and $2 \mathrm{M}-\mathrm{NaCl}$ (the value at $2 \mathrm{M}$ is given in Table 1). This increase is approximately proportional to the $\mathrm{NaCl}$ concentration increase (data not shown). To demonstrate that the renaturation involved condensed denatured DNA molecules (at least for the higher salt concentrations), we employed a centrifugation assay: following a 15 minute incubation in the conditions of Figure 5(a), the samples were centrifuged for ten minutes at $10,000 \mathrm{revs} / \mathrm{min}$ in a Sigma $2 \mathrm{MK}$ centrifuge. The radioactivity present in the pellet and the supernatant of each sample was determined (Fig. 5(b)) and portions of these samples were further analyzed by gel electrophoresis. Figure $5(\mathrm{~b})$ demonstrates that more than $80 \%$ of the total DNA is condensed at high salt concentrations (1.7 and $2 \mathrm{~m}-\mathrm{NaCl})$. The gel analysis further indicates that the 125-nucleotide fragment is never found in the pellets but always in the supernatants (data not shown; according to Fig. 5(a), very little renaturation is detected for this fragment at any salt concentration). In contrast, the totality of the 564nucleotide fragment is pelleted at these high concentrations. Taken together these results clearly demonstrate that the renaturation of the 564 nucleotide fragment involves condensed molecules.

\section{(e) A protein-free strand exchange experiment}

The strand-transfer assay used in this experiment is essentially the assay of McCarthy et al. (1988). As a double-stranded DNA substrate, we have used $H p a I I$-cleaved, $33^{\prime}-{ }^{32} \mathrm{P}$-end labeled $\phi \mathrm{X} 174 \mathrm{RF}$ DNA. This substrate consists of five restriction fragments. As shown in Figure 6 (lanes 1 and 2), agarose gel
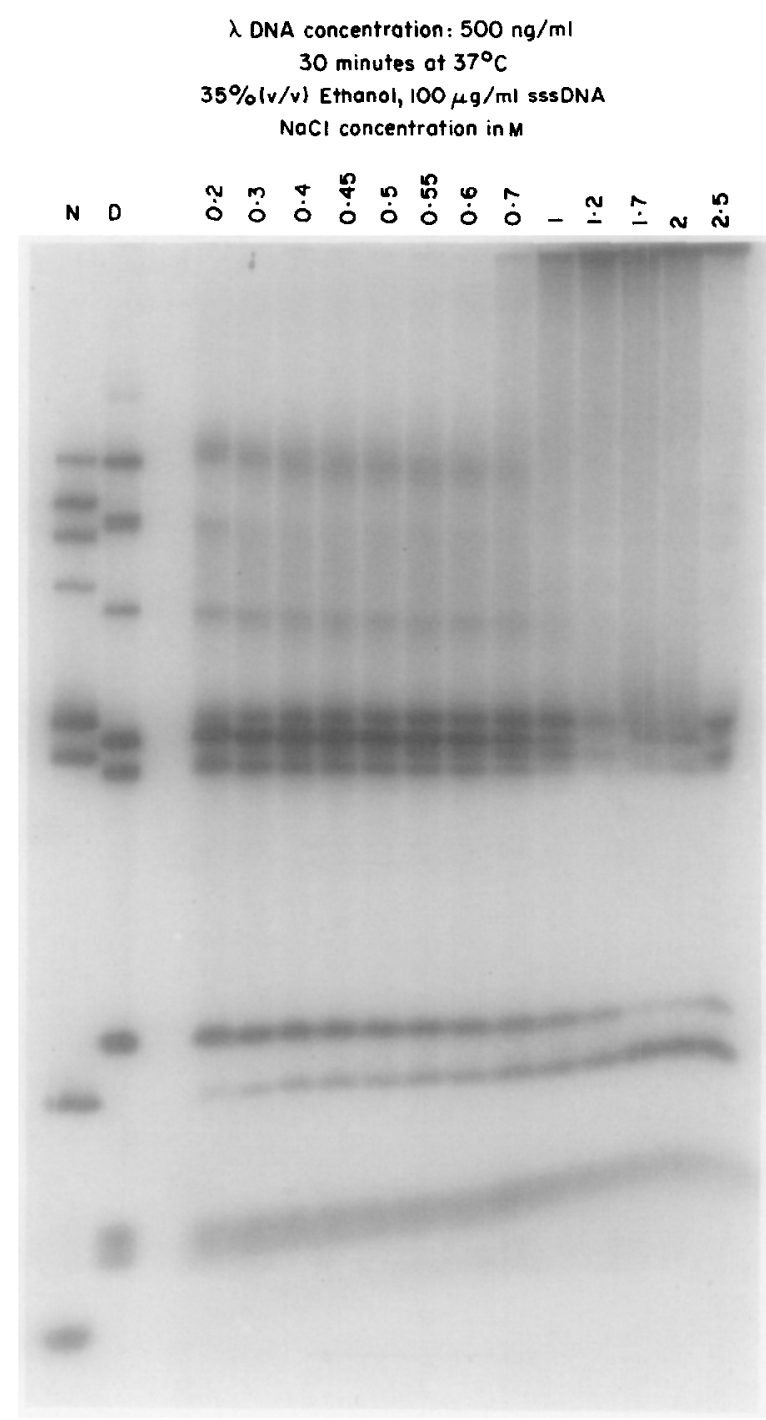

(a)

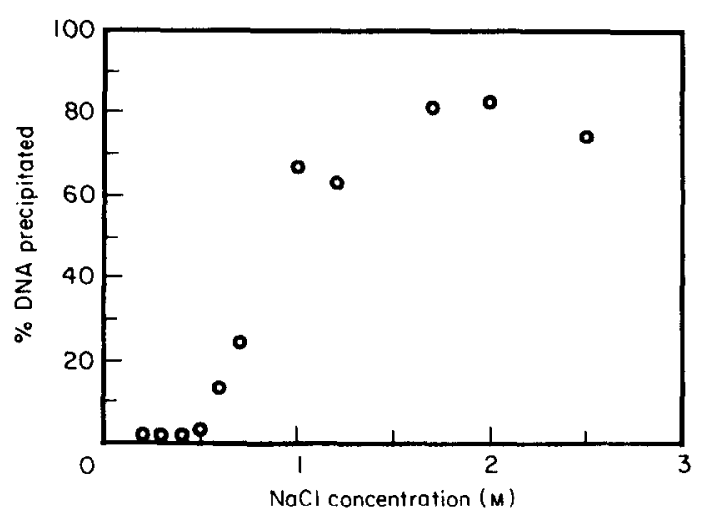

(b)

Figure 5. (a) Effects of various $\mathrm{NaCl}$ concentrations on the renaturation of heat-denatured $\lambda \mathrm{DNA}(500 \mathrm{ng} / \mathrm{ml})$ at $37^{\circ} \mathrm{C}$ in $35 \%(\mathrm{v} / \mathrm{v})$ ethanol plus $100 \mu \mathrm{g}$ native sonicated salmon sperm (sss) DNA/ml. Lanes $\mathrm{N}$, native DNA; lane D, denatured DNA; following lanes, common incubation time of $30 \mathrm{~min}$. $\mathrm{NaCl}$ concentration (in $\mathrm{M}$ ) is indicated above each lane. (b) DNA condensation assay for the conditions used in (a). 


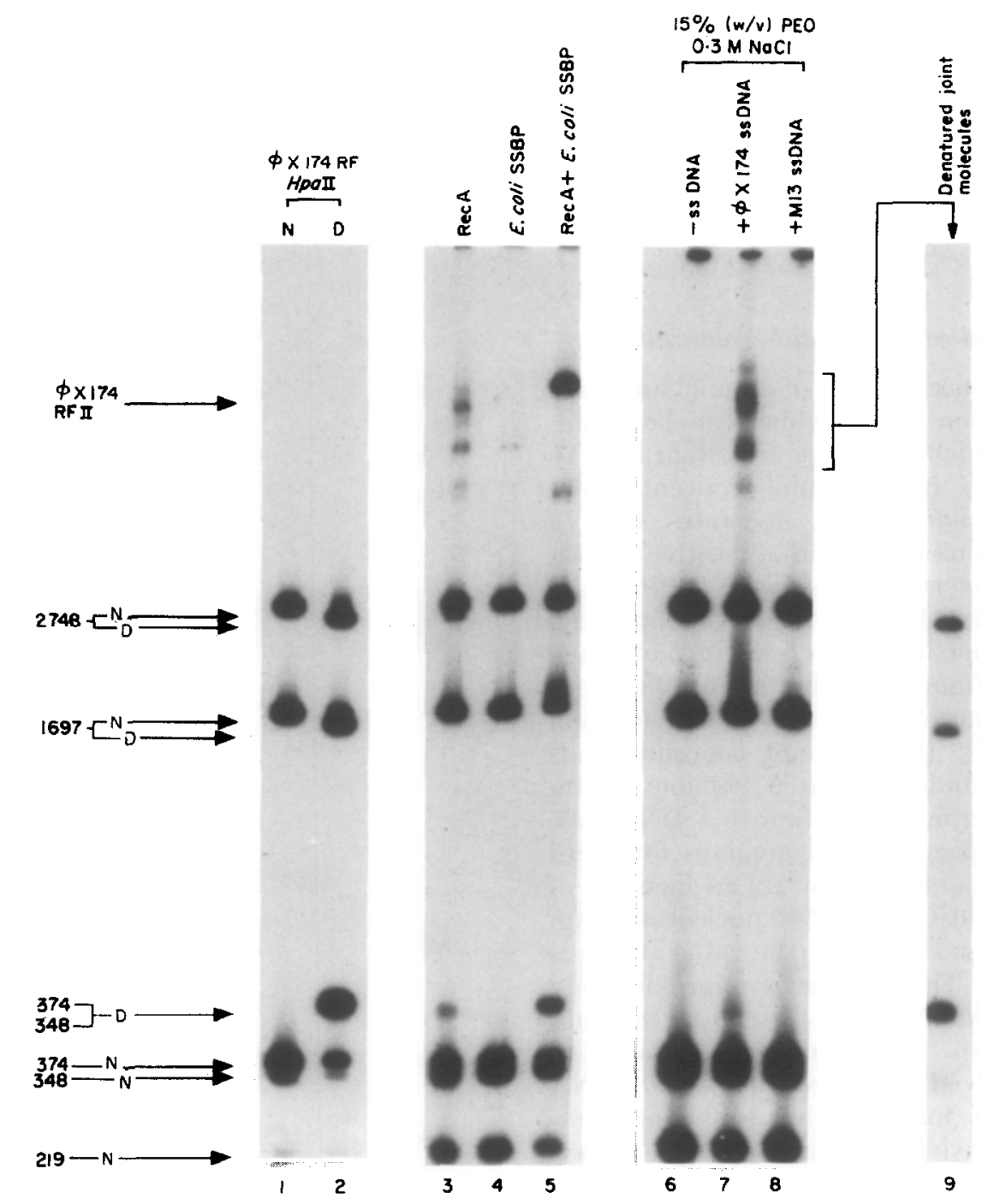

Figure 6. Strand exchange experiments. All reactions were performed at $37^{\circ} \mathrm{C}$ for $45 \mathrm{~min}$. Lane 1, native DNA; lane 2 , alkali-denatured DNA. The DNA used in these 2 lanes was end-labeled with T4 DNA polymerase (spee. radioact. $5 \times 10^{6} \mathrm{cts} / \mathrm{min}$ per $\mu \mathrm{g}$ ). The DNA used in the other lanes was end-labeled with the Klenow fragment of DNA polymerase I (spec. radioact. $6.5 \times 10^{5} \mathrm{cts} / \mathrm{min}$ per $\mu \mathrm{g}$ ). Strand-transfer reactions were carried out in a $20 \mu \mathrm{l}$ volume containing $25 \mathrm{~mm}$-Tris $\mathrm{HCl}(\mathrm{pH} \mathrm{7} \cdot 4), 10 \mathrm{~mm}-\mathrm{MgCl}_{2}, 1 \mathrm{~mm}$-dithiothreitol and $1 \mathrm{~mm}$-ATP (for lanes 3, 4 and 5). DNA concentrations used were $2 \mu \mathrm{g} / \mathrm{ml}$ for $H p a I I-c l e a v e d$ (replicative form) $\phi X 174$ DNA, and $1 \mu \mathrm{g} / \mathrm{ml}$ for $\Phi$ X 174 viral (+) strand DNA (lanes 3, 4 and 5); $10 \mu \mathrm{g} / \mathrm{ml}$ for $\mathrm{HpaII}$-cleaved (replicative form) $\phi$ X174 DNA (lanes 6, 7 and 8); $10 \mu \mathrm{g} / \mathrm{ml}$ for M13mpl8 viral (+) strand (lane 8); $12.5 \mu \mathrm{g} / \mathrm{ml}$ for $\phi \times 174$ viral (+) strand (lane 7 ). Protein concentrations used: RecA $260 \mu \mathrm{g} / \mathrm{ml}$ (lanes 3 and 5); $E$. coli SSBP $230 \mu \mathrm{g} / \mathrm{ml}$ (lanes 4 and 5). Lanes 6,7 and 8 , the reactions were performed in $0 \cdot 3 \mathrm{M}-\mathrm{NaCl}$, $15 \%(\mathrm{w} / \mathrm{v})$ PEO.

electrophoresis allows the discrimination between native and denatured forms of these five fragments. In particular, the denatured forms of the 374 and 348-nucleotide fragments are clearly distinguished from their native counterparts: they comigrate as a broad band designated

$$
\left.\begin{array}{l}
374 \\
348
\end{array}\right\} \text { D. }
$$

In the presence of the $(+)$ strand of $\phi \times 174$, the RecA protein catalyzes the formation of joint molecules between the double-stranded substrate and the single-stranded substrate. Figure 6 (lane 3) shows that several slow migrating ${ }^{32} \mathrm{P}$-labeled species appear. In addition, we also observe the appearance of denatured material corresponding to the $374+348$ fragments. This band is not detected when $E$. coli single-stranded binding protein is used alone in the presence of the single and doublestranded substrate (Fig. 6, lane 4); in this case we observe only trace amounts of joint molecules. The stimulation of the RecA-strand transfer by SSBP is shown in lane 5 of Figure 6. The denatured material corresponding to the $374+348$ fragment increases; the majority of the joint molecules consist of a single band which, according to ethidium bromide staining, comigrates with the relaxed replicative form (RFII) of $\phi \times 174$ (data not shown; indicated by the upper arrow on the left side of Fig. 6). 
A crucial aspect of this strand-transfer assay is the absence of denatured DNA molecules for the $374+348$ fragments in the double-stranded substrate. In the case of the reaction carried out in the presence of $E$. coli SSB protein, for instance, we observe the very weak appearance of joint molecules, although this protein is not known to be able to perform strand-exchange reactions. We may interpret this reaction as the renaturation of the (partially) denatured 219-nucleotide fragment present in the double-stranded substrate (the denatured form of this fragment comigrates with the native form of the 348-nucleotide fragment; therefore its integrity cannot be assessed). To rule out this possibility, we have looked for the presence of denatured $374+348$ fragments in the doublestranded substrate, and we have been unable to find them even on overexposed autoradiography (data not shown). We therefore conclude that the denaturation of the $374+348$ fragments observed here is the consequence of the strand-transfer reaction.

The protein-free strand exchange experiment is displayed on lanes 6 to 8 in Figure 6 . In the presence of $15 \%(\mathrm{w} / \mathrm{v}) \mathrm{PEO}$ and $0.3 \mathrm{~m}-\mathrm{NaCl}$ we observed the associations of the double-stranded DNA substrate and the $(+)$ strand of $\phi \times 174$ (lane 7 ). Furthermore, the presence of denatured material corresponding to the $374+348$ fragments can be noted. These two phenomena are not observed in the absence of single-stranded DNA or in the presence of M13mp18 single-stranded DNA (lanes 6 and 8). This last experiment demonstrates the necessity of homology in protein-free strand transfer.

To investigate the structure of the joint molecules obtained with the $(+)$ strand of $\phi \times 174$ ss DNA, a portion of the reaction was submitted to the same electrophoretic analysis. Following migration, a broad band corresponding to the joint molecules (indicated by a bracket on Fig. 6) was sliced out of the gel. The radioactive material, which represents approximately $2 \%$ of the input DNA, was recovered by the NaI technique (Vogelstein \& Gillespie, 1979), denatured in alkali and reanalyzed by gel electrophoresis (Fig. 6, lane 9). The alkali treatment releases three bands corresponding to the 2748,1697 and $374+348$ denatured fragments A trace amount of the 219 fragment is also detected. In the case of the 2748 and 1697 fragments, the NaI treatment alone was sufficient to release these fragments in their native configuration (data not shown); we interpret this fact as the consequence of a partial transfer for these fragments.

\section{Discussion}

(a) Renaturation of condensed DNA

In the present work we report an investigation of optimal conditions for DNA renaturation.

If we consider the renaturation of condensed denatured DNA molecules and show that it proceeds faster than the similar reaction involving these molecules in solution, then we possess a basic answer to the optimization problem; indeed, the excluded-volume approach works by reducing the volume accessible to the denatured DNA molecules and this volume cannot be reduced more than by DNA condensation.

Therefore, the basic idea developed in these studies was to investigate the helix-coil transition involving condensed DNA molecules (transition $3 \leftrightarrows 4$ in Fig. 1). Our experimental scheme, which starts with denatured DNA molecules in solution, in this study involves three successive steps: (1) the condensation of denatured DNA; (2) the renaturation of condensed DNA, yielding condensed doublestranded DNA; (3) the "decondensation" of doublestranded DNA, yielding double-stranded DNA molecules in solution, which are analyzed by electrophoresis.

In this scheme, the analysis of the kinetics of renaturation can be affected by the preceding and (or) the subsequent steps; we have observed, for instance, that renaturation lags for several minutes at $60^{\circ} \mathrm{C}$ in the presence of $\mathrm{Mg}^{2+}$. This lag can probably be attributed to the condensation reaction.

It is also important to observe that the conditions of stable condensation may differ for single and double-stranded DNA. This can be illustrated by two examples: (1) Since single-stranded DNA has a linear charge density lower than that of doublestranded DNA (see Manning, 1978), the condensation by multivalent ions is likely to require higher concentrations of these ions for single-stranded DNA compared to double-stranded DNA. At intermediate concentrations, only double-stranded DNA would be stably condensed. (2) In the PERT system, on the contrary (as discussed below), only single-stranded molecules are condensed.

\section{(i) Demonstration that the renaturation experiments involve condensed $D N A$}

(1) Direct physical demonstration for the ethanol and salt experiment. Various physical techniques (reviewed by Williams et al., 1981) are available to investigate the condensation of macromolecules. Since we expected not only individual collapses but also aggregation (and, indeed, the presence of aggregates at the top of the gels is a striking feature of our experiments), we have employed a simple sedimentation assay to demonstrate condensation in the ethanol and salt-induced renaturation experiments. In the presence of $2 \mathrm{M}-\mathrm{NaCl}$, more than $80 \%$ of the denatured DNA sediments after a brief incubation at $37^{\circ} \mathrm{C}$. Furthermore, the non-reassociating 125 nucleotide fragment does not precipitate; the precipitation of the $564 \mathrm{bp}$ fragment is therefore essentially complete, which directly demonstrates its condensed state. The same sedimentation studies also strongly suggest that the renaturation performed in the presence of PEO involves condensed molecules (data not shown). In the presence of low concentrations of polymers, however, it remains to 
be seen if the acceleration of the renaturation rates is accompanied by DNA condensation. In the presence of $\mathrm{Mg}^{2+}$ or hexamminecobalt(III) (following a brief incubation at $68^{\circ} \mathrm{C}$ ), only 65 to $85 \%$ of the DNA material is precipitated by the same sedimentation assay (data not shown); since the precipitation was not always complete in this assay, we did not rely on these experiments solely to demonstrate condensation in these cases.

(2) Theoretical arguments. We have shown that divalent $\left(\mathrm{Mg}^{2+}\right)$ or trivalent (hexamminecobalt(III)) ions, which induce the condensation of double-stranded DNA, increase the rate of renaturation. That the observed renaturations may directly involve condensed DNA molecules is supported by two arguments below.

Ionic strength dependence of the renaturation rate. The first argument, developed in the case of hexamminecobalt(III), is the fact that the renaturation rate does not follow a power-law-type dependence on the salt concentration, as observed for DNA molecules in solution. The breakdown of this power law dependence shows that the reaction operates through a different mechanism. Furthermore, the fact that increasing salt concentration operates in such a highly co-operative manner is indicative of a critical phenomenon. The coil-globule transition is the most likely candidate for this critical phenomenon.

Scaling arguments. The second argument is a scaling argument. According to the generalization made here of the scaling law introduced by Wetmur $\&$ Davidson (1968), the relationship between $k_{2}$ and $N$, the degree of polymerization, is $k_{2} \sim R^{d} / N$, yielding $k_{2} \sim N^{v d-1}$ if $R \sim N^{v}$.

In the presence of $\mathrm{NaCl}$ alone, the experimental relationship between $k_{2}$ and $N$ is $k_{2} \sim N^{0 \cdot 50}$ (Wetmur \& Davidson, 1968), $k_{2} \sim N^{0.45}$ (in 0.18 M$\mathrm{NaCl}$, at $60^{\circ} \mathrm{C}$ : Hinnebusch et al., 1978), or $k_{2} \sim$ $N^{0.40}$ in our experiments (Fig. 2(c)). As observed in the theoretical section, salt effect or DNA concentration effect could account for the differences between these three relationships, which are all, however, roughly in agreement with the $N^{0.50}$ scaling law introduced by Wetmur \& Davidson (1968)

It is clear that this $N^{0.50}$ scaling law is not followed in the experiments reported in the present article. In a most general way, we interpret the breakdown of this law as an indication that the reaction operates through a different mechanism.

The most spectacular cvidenees for the break down of the scaling law are: (a) the description of conditions (e.g. $30 \%$ PEO), where the 125nucleotide fragment renatures faster than the 564nucleotide fragment; (b) the lack of renaturation of the 125-nucleotide fragment in the presence of $\mathrm{Mg}^{2+}$ at $68^{\circ} \mathrm{C}$ and $60^{\circ} \mathrm{C}$ (well below the melting temperature; see Dove \& Davidson, 1962); we explain this lack of renaturation by the fact that the 125nucleotide fragment is not condensed at $50 \mathrm{~mm}$ $\mathrm{Mg}^{2+}$.

In the conditions of the hexamminecobalt(III) reactions (a highly dilute DNA solution of $5 \times 10^{-8} \mathrm{~g} / \mathrm{ml}$ ), it is very likely that denatured DNA molecules are not entangled (in other words are below the overlap threshold concentration $C^{*}$ : see de Gennes, 1985). In such conditions, individual collapse of the denatured molecules should take place before any aggregation; the renaturation should therefore involve completely collapsed denatured molecules (since the small size of the hexamminecobalt(III) ion should not cause any steric hindrance to a full collapse). The generalized scaling law predicts $k_{2} \sim N^{0}$ (since we expect $R \sim$ $N^{1 / d}$ ). The renaturation of the 125 and 564nucleotide fragments occurs at very similar rates in the presence of hexamminecobalt(III) at high temperature $\left(73\right.$ and $\left.78^{\circ} \mathrm{C}\right)$; we view these experiments as a confirmation of this prediction.

\section{(b) Considerations on the mechanism of PERT}

\section{(i) PERT involves condensed denatured DNA}

We have investigated the salt dependency of the renaturation rate in PERT. In this system we have shown that the acceleration of the renaturation rates occur over a strikingly narrow range of $\mathrm{NaCl}$ concentration. These results are clearly incompatible with a power-law-type relationship between the salt concentration and the renaturation rate; we conclude that in this system also, renaturation involves condensed denatured molecules. In addition to this salt concentration effect, a typical scaling effect shows up: the longer DNA fragment renatures first, higher $\mathrm{NaCl}$ concentrations are required to renature smaller fragments

\section{(ii) Further considerations}

The mechanism of PERT requires a special discussion, because the concept of a two dimensional renaturation raises specific topological problems; indeed, the renaturation process yields a double-stranded structure with intertwining strands (a plectonemic structure: see Radding, 1989). 'This is a three-dimensional process, which is topologically forbidden in two dimensions. It may be dealt with by considering the interface as having a finite threedimensional thickness with small probabilities of DNA strands coming various distances off the surface. Alternatively, one could hypothesize that only the creation of a double-stranded structure without intertwining (a paranemic structure) occurs at the interface, and that this structure, which is not stably condensed, is expelled from the interface. In this hypothesis the intertwining would occur in the water phase.

Finally, we want to add another argument to favor the possible biological significance of PERT: PERT apparently operates through a reduction of dimensionality in the renaturation system from $d=3$ to $d=2$. From this point of view, the possible biological relevance stems from the general impor tance of the reduction of dimensionality in bio logical diffusion processes (Adam \& Delbrück, 1968) 
(c) DNA condensation as a unifying explanation of the acceleration of renaturation

Taken together, all our results have led us to consider DN $\Lambda$ condensation as a unifying explanation of the acceleration of renaturation described in the experiments reported here or in the literature. In particular, we believe that the acceleration of renaturation by single-stranded DNA binding proteins involves condensed molecules. Other types of explanations have been proposed for these accelerations.

(1) The acceleration could result from a decrease of the melting temperature $\left(t_{\mathrm{m}}\right)$; this is the case in the catalysis by the gene 32 single-stranded binding protein (Alberts \& Frey, 1970), or the ethanol/salt catalysis (see Herkovits et al., 1961, for the $t_{\mathrm{m}}$ in this system); however, this explanation does not apply to PEO, $\mathrm{Mg}^{2+}$ or hexamminecobalt(III), since all these reagents are known to increase rather than decrease melting temperatures (see Laurent et al., 1974; Dove \& Davidson, 1962; Karpel et al., 1980).

(2) A different type of explanation would rely on the specificity of the interaction between the accelerating compound and single-stranded DNA molecule. Single-stranded DNA binding proteins, for instance, would increase renaturation rate because of their high affinity for single-stranded DNA molecules. Again, this explanation does not apply to $\mathrm{Mg}^{2+}$ or hexamminecobalt(III), which have a higher affinity for double-stranded DNA molecules rather than for single-stranded DNA molecules (Dove \& Davidson, 1962; Karpel et al., 1980). Furthermore, the variety of the chemical compounds able to promote the acceleration does not encourage the search for an explanation based on the specific chemical nature of each of these compounds the same argument has been set forward by Manning (1989) for DNA condensation).

We helieve that DNA condensation differs from these explanations in terms of explanatory power and predictive value. This explanation has a higher predictive value; all compounds that can condense single-stranded DNA molecules should also be able to accelerate their renaturation. In addition to the conditions described here we have also obtained accelerations of renaturation with polyamines (such as spermidine ${ }^{3+}$ or spermine $e^{4+}$ ) and by protonation (data not shown). These compounds are known to condense DNA molecules (see Gosule \& Schellman, 1976; Dore $t$ t al., 1972). The importance of a specific chemical structure reappears when one needs to explain the differences observed between various compounds, for instance, the collapse induced by a single-stranded DNA binding protein is not complete (i.e. leading to a globule with a radius $R \sim N^{1 / 3}$ ), probably because of the steric hindrance introdued by the shape of the protein; this leads to collapsed DNA molecules which can be in an unusual extended configuration. This configuration may explain (1) the lack of detectable aggregation of such systems and (2) different scaling laws for the renaturation rates (see Christiansen \& Baldwin,
1977; note, however, that Pontius \& Berg (1990) have also observed that $k_{2}$ is independent of $N$ in the renaturation performed by the mammalian heterogeneous nuclear ribonucleoprotein Al protein).

The study reported here provides a basic answer to the problem of the optimization of renaturation; optimal conditions are not obtained with DNA molecules in solution, but rather with condensed molecules. It should be noted, however, that conditions optimal for a given size of DNA molecules are not necessarily optimal for all sizes (compare the renaturation rates for the 125 and 564-nucleotide fragment in the presence of $\mathrm{PEO}$ ).

Our investigation leaves unanswered several questions dealing with the mechanism of the renaturation of condensed DNA molecules. We have seen that in various cases the rate of renaturation can be greater for the smaller fragments; this cannot be explained by the law $k_{2} \sim R^{d} / N$.

In the presence of $30 \% \mathrm{PEO}$, for instance, the coil-globule transition involves denatured DNA molecules with a high local concentration (due to the excluded volume effect by PEO), and therefore strongly entangled. It is reasonable to expect that following the transition, DNA molecules will diffuse by a reptation-type motion (de Gennes, 1985; Odijk, 1983). Such a motion may provide an explanation for this unexpected scaling effect.

For the cation effects that lack many of the above uncertainlies, it is worth noting that the highest rates obtained here (for instance, for the $125 \mathrm{bp}$ fragment, $5 \times 10^{9} \mathrm{M}^{-1} \mathrm{~s}^{-1}$ ) are near the limits set by the theoretical rates expected in a diffusion controlled reaction. Using a modified Smoluchowski equation (eqn (3) of von Hippel \& Berg, 1990), the maximal association rate for the bimolecular association of compounds $\mathrm{A}$ and $\mathrm{B}$ is equal to:

$$
k_{\text {assoc }}=4 \pi \kappa a f\left(D_{\mathrm{A}}+D_{\mathrm{B}}\right) N_{0} / 1000 .
$$

Taking the diffusion constants $D_{\mathrm{A}}=D_{\mathrm{B}}=1 \cdot 3 \times$ $10^{-6} \mathrm{~cm}^{2} \mathrm{~s}^{-1}$ for the $125 \mathrm{bp}$ fragment, $f=1$ (no net electrostatic effects), $\kappa=1 / 125$ for the fraction of the interactions resulting in one correct base-pair, and interaction distance $a=5 \mathrm{nM}$, we obtain $k_{\text {assoc }}=$ $8 \times 10^{7} \mathrm{M}^{-1} \mathrm{~s}^{-1}$.

It is therefore clear that in optimal conditions, the observed renaturation rate is at or even above the calculated three-dimensional diffusion limit, which is theoretically consistent with a limited search space in the condensed phase. This phase would merely consist of two or more molecules bound together at sites other than correct basepairs.

\section{(d) The structure of the DNA aggregates}

The existence of aggregated structures is an important feature of the experiments deseribed here. According to gel analysis, the aggregates involve essentially large (greater than $2 \mathrm{~kb}$ ) DNA fragments. What is the structure of these aggregates? In the case of the renaturation of randomly sheared 


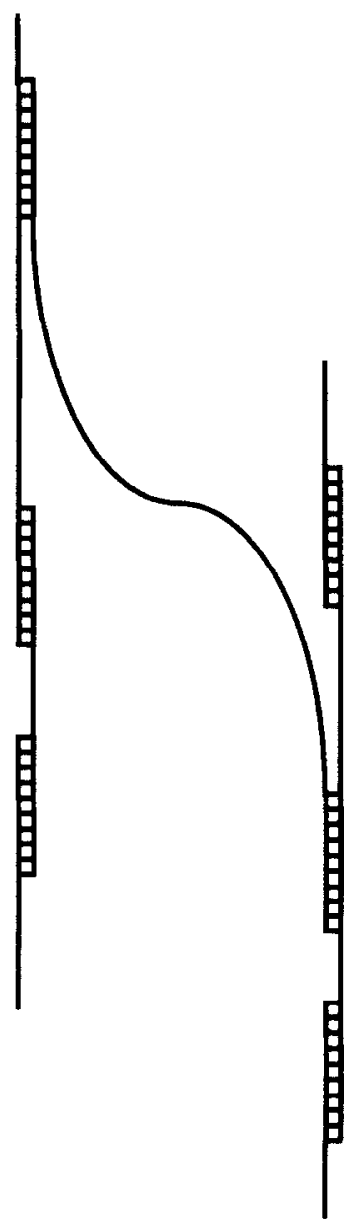

(a)

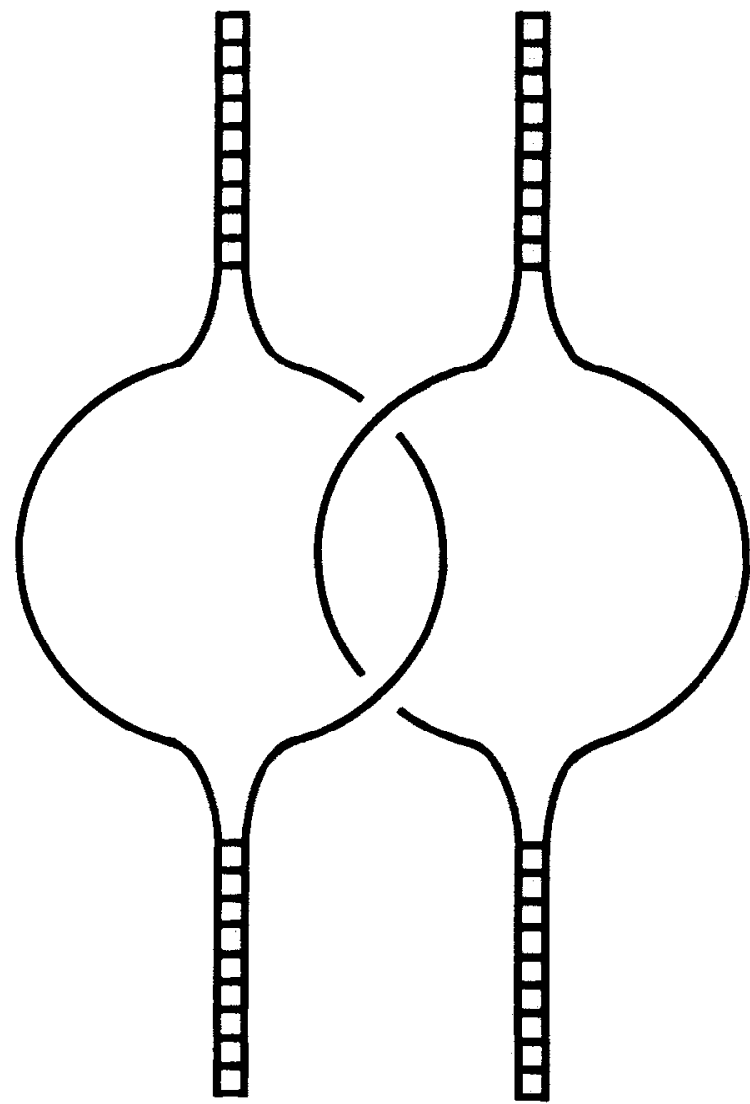

(b)

Figure 7. (a) Schematic representation of a gel produced by the renaturation of randomly sheared DNA molecules. (b) Schematic representation of a gel produced by the renaturation of DNA molecules obtained by enzymatic restriction cleavage.

DNA molecules, aggregation may clearly result from the formation of giant molecules as schematized in Figure 7(a); the term hyperpolymer has been proposed to describe these structures (Britten et al., 1974). Figure 7(a) schematizes two possible components of these structures: long, linear chains, in which branching may occur. The branched structures, however, are not expected to be stable, due to strand displacement, unless strand displacement is prevented by entanglement effects. In the present study we have used a mixture of DNA molecules obtained by enzymatic restriction cleavage, which cannot produce the long linear chains shown in Figure 7(a). In Figure 7(b) we propose a topological arrangement which can explain the structure of the aggregates. It can be seen that this is the structure of "olympic gels" (see de Gennes, 1985, p. 132), which are known as cateranes for circular single or double-stranded DNA molecules. It is important to remark that such a structure could be obtained even with a single restriction fragment molecule. In contrast with three-dimensional reactions, the experiments carried out with PERT differ in two respects: (1) no aggregates are detected; (2) the renaturation of the larger DNA fragments is efficiently performed (see Fig. 5(b)). These two facts are strong arguments in favor of the strict twodimensional nature of this reaction: (1) polymers are expected to be strongly segregated rather than entangled in two dimensions (de Gennes, 1985 . p. 61$) ;(2)$ the structure described in Figure $7(\mathrm{~b})$ is forbidden in two dimensions.

\section{(e) The physical basis of genetic recombination}

The idea that the double-helical structure of DNA may provide an explanation for genetic recombination traces back to the original description of this structure (for a historical account, see Holliday, 1990). The overwhelming stability of the DNA double-helix in solution is a major physical obstacle to a strand-exchange reaction in vitro. How is this obstacle overcome in vivo? The biochemical approach to this question has led to the description of proteins such as RecA protein, which are involved in vivo in genetic recombination and can perform strand-exchange reactions in vitro. The fact that the RecA protein can condense single-stranded 
as well as double-stranded DNA molecules has prompted us to hypothesize that the simultaneous condensation of these molecules may suffice to perform a strand-exchange reaction. To test this hypothesis, we have induced the condensation of $\phi \mathrm{X} 174$ DNA molecules $((+)$ strand and HpaIIcleaved replicative form) by addition of poly(ethylene oxide). In this experiment we have observed the transfer of the $348+374$ nucleotide $H$ paII fragments as well as a partial transfer of the two largest $H p a I I$ fragments $(1697+2748$ nucleotide fragments). The interactions between PEO and nucleic acids are essentially repulsive (see Lerman, 1973); therefore, in order to explain this result, we cannot rely, as in the case of the RecA protein, on specific associations of the agent that permit the strand-transfer reaction with nucleic acids. As in the case of the acceleration of DNA renaturation, we belicve that DNA condensation offers a unifying explanation for these experiments as well as for various highly co-operative phenomena that have been observed with RecA or similar proteins.

In other words, at the molecular level, genetic recombination is made possible by DNA condensation; an explanation of the physical basis of genetic recombination will originate from an understanding of the particular structural and functional properties of condensed DNA. The condensation of nucleic acids (whether by PEO or RecA) increases their local concentration and therefore should favor the kinetics of the strand-exchange reaction. To explain the strand-exchange reaction, we further need to show that the secondary structure of the doublehelix is destabilized in condensed DNA.

First, a major and well-established fact is that the double-helical structure of DNA differs in fibers and in solution; $B$-form crystalline DNA contains $10 \cdot 0$ base-pairs per helical turn versus 10.4 to 10.5 per helical turn in solution (Wang, 1979). Here, however, we are not directly interested in the crystalline state of DNA, which is devoid of functional properties, but rather with the liquidcrystalline state, which retains the fluidity necessary for chemical reactions. Zimmerman \& Pheiffer (1979) have shown that the structural helical parameters of DNA fibers are conserved under extreme conditions of hydration. Because these conditions are those expected to prevail in liquid-crystalline DNA, it is reasonable to hypothesize that the secondary structure of DNA in a liquid crystalline form is that of $B$-DNA fibers.

Several types of investigations further favor the idea that the transition from solution to liquid crystalline DNA greatly alters the secondary structure: (1) DNA inside bacteriophage heads is known to be in a partially denatured conformation (Tikchonenko et al., 1966, 1971); (2) DNA condensed by PEO (Laemmli, 1975) is cleaved by a single-strand-specific endonuclease (see also Marx \& Reynolds, 1982: this cleavage can, however, be explained solely by the existence of local "kinks", i.e. dislocations (see Kléman, 1989) in liquid crystalline DNA); (3) the polymer and salt condensation of
DNA possesses a fairly sharp thermal transition whose mid-point $\left(t_{\mathrm{m}}^{\prime}\right)$ is correlated linearly with the $\mathrm{G}+\mathrm{C}$ concentration of the condensed DNA (Cheng $\&$ Mohr, 1975), as does the melting temperature $\left(t_{\mathrm{m}}\right)$; (4) finally, the experiments of Svaren et al. (1987) demonstrate that the condensation of small DNA fragments in an aqueous solvent can induce the denaturation of these fragments (note that the title of the article of Svaren et al. (1987) is slightly misleading, since ethanol is not required to induce denaturation). All these experiments clearly point to the fact that the double-helix is destabilized in liquid crystalline DNA and therefore accessible to strand exchange reactions. The nature of the physical interactions responsible for this phenomenon may be guessed. It is known that DNA molecules strongly repel each other when their interaxial distance is about $35 \AA$ or shorter; these repulsive forces, called hydration forces, probably arise from the local ordering of the water molecules near the DNA surface (Podgornick et al., 1989; Reddy \& Berkowitz, 1989). We hypothesize that the local ordering of water molecules and the subsequent dehydration of the DNA molecules are the physical causes of the destabilization of the double-helix. The importance of local dehydration in condensed DNA has also been stressed in the case of the transitions between the various types $\left(A, A^{\prime}, B, C\right.$, $\left.Z, Z^{\prime}\right)$ of double-helices in the fiber and crystalline state (Drew et $a l ., 1980$ ).

\section{(f) The functional properties of condensed DNA}

In the present paper, we have seen that condensa tion profoundly modifies complementary recognition in single-stranded and double-stranded DNA molecules. Because complementary recognition is such a major functional property in nucleic acids, we believe that the importance of the modifications described here are sufficient to advocate the systematic study of the functional properties of condensed DNA. Because of the relationship between macromolecular crowding and DNA condensation, this proposal joins the research program set out by Zimmerman and co-workers (see Zimmerman \& Harrison, 1987). As an example of a possible investigation, we shall mention here the study of DNAprotein interactions (e.g. the lac-repressor-operator interactions: see Riggs et al., 1970; Richter \& Eigen, 1974), how are these interactions affected by DNA condensation?

Striking examples of the functional properties of condensed DNA can readily be found in the literature (see, for instance, Srivenugopal et al., 1987; Baeza et al., 1987).

Finally, according to the experiments described here, condensed nucleic acids possess an unwinding activity that is of interest for the problem of the origin of life (a major problem associated with the self-replication of nucleic acids is that of reduplication, as observed by Joyce (1989), the appearance of an unwinding activity would have been a priority during early evolution). 


\section{Conclusion}

In the present article we have studied the consequences of a critical phenomenon, DNA condensation, on the functional properties of these molecules. We have shown that obstacles that appear insuperable with single or double-stranded DNA in solution can be overcome in condensed DNA. The experiments described here raise the recurrent question of the definition of realistic physiological conditions for in vitro experiments; it is possible that the physiologically relevant form of DNA might be the condensed, not the solution, form.

We thank R. Baldwin and E. Yéramian for thoughtful suggestions, J. Massoulié and W. Guschlbauer for the critical reading of the manuscript and ( $x$. Masson for help in densitometric analysis. J.L.S. expresses his gratefulness to $\mathrm{F}$. Rougeon for his constant support during this work. Supported by DOE grant DE-FG02-87R60565 to G.M.C. and a grant of the Association Française des Myopathes to J.L.S.

\section{References}

Adam, G. \& Delbrück, M. (1968). Reduction of dimensionality in biological diffusion processes. In Structural Chemistry and Molecular Biology (Rich, A. \& Davidson, N. eds). Freeman, San Francisco.

Alberts, B. M. \& Frey, L. (1970). T4 bacteriophage gene 32: a structural protein in the replication and recombination of DNA. Nature (London), 227, 1313-1318.

Amasino. R. M. (1986). Acceleration of nucleic acid hybridization rate by polyethylene glycol. Anal. Biochem. 152, 304-307.

Ausubel, F. M., Brent, R., Kingston, R. E., Moore, O. D. Seidman, J. G., Smith. J. A. \& Struhl, K. (eds) (1989). Current Protocols in Molecular Biology. Wiley. New York.

Baeza. I., Gariglio, P., Pangel, L. M., Chavez, P.. Cervantes, L., Arguello, C.. Wong, C. \& Montañez, (. (1987). Electron microscopy and biochemical properties of polyamine-compacted DNA. Biochemistry, 26. $6387-6392$

Blumen. A. \& Schnörer, H. (1990). Fractals and related hierarchical models in polymer science. Angew. Chem. Int. Ed. Engl. 29, 113-125.

Bouligand, Y. (1985). Brisures de symétrie et morphogenèse biologique. C.R. Acad. Sci. (Paris) Série Gén. La Vie des Sciences, 2, no. 2, 121-140.

Britten, R. J., Graham, D. E. \& Neufeld, B. R. (1974). Analysis of repeated DNA sequences by reassociation. Methods Enzymol. 29E, 363-406.

Cantor, C. R. \& Schimmel, P. R. (1980). Biophysical Chemistry, Part III. The Behaviour of Biological Macromolecules, chapters 22 and 23 . W. H. Frecman and Co., New York.

Chase, J. W. \& Williams, K. R. (1986). Single-stranded DNA binding proteins required for DNA replication. Annu. Rev. Biochem, 55, 103-136.

Cheng, S. M. \& Mohr, S. C. (1975). Condensed state of nucleic acids. II. Effects of molecular size, base composition and presence of intercalating agents on the $\psi$ transition of DNA. Biopolymers, 14, 663-674

Christiansen. C. \& Baldwin. R. L. (1977). Catalysis of DNA reassociation by the Escherichia coli DNA binding protein. A polyamine-dependent reaction. $\%$ Mol. Biol. 115, 44]-454.
Cox, M. M. \& Lehman. I. R. (1987). Enzvmes of general recombination. Annu. Rev. Biochem. 56. 229-262

de Gennes, P. (1. (1975). The Physics of Liquid Crystals. Clarendon, Oxford

de Gennes. P. G. (1985). Scaling Concepts in Polymer Physics. Cornell Iniversity Press. Ithara.

Dore, E. Frontali. (. \& Gratton. E. (1972). Physico chemical description of a condensed form of DNA Biopolymers, 11, 443-459.

Dove. W. F. \& Davidson. N. (1962). Cation effects on the denaturation of DNA. J. Mol. Biol. 5, 467-478.

Drew, H., Takano, T., Tanaka, S., Itakura, K. \& Dickerson, R. E. (1980). High-salt d(CpGpCp(x), a left-handed $Z$ ' DNA double helix. Nature (London.). 286, 567-573

Evdokimov, Yu. M., Pyatigorskaya, T. L., Polyvtsev. O. F.. Akimenko, N. M.. Kadykov, V. A.. Tsvankin. D. Ya. \& Varshavaky, Ya. M. (1976). A comparative $\mathrm{X}$-ray diffraction and circular dichroism of DNA compact particles formed in water-salt solutions containing poly(ethylene glycol). Nucl. Acid Res. 3 $2353-2366$.

Fisher, M. E. (1966). Effects of excluded volume on phase transitions in biopolymers. J Chem. Phys. 45. 1469. 1473.

Flory, P. J. (1953). Principles of P'olymer (hemistry. Cornell University Press. Ithaca.

Gierer. A. (1981). Generation of biological patterns and form: some physical, mathematical and logical aspects. Prog. Biophys. Mol. Biol. 37, 1-47.

Gosule, L. C Schellman, J. A. (1976). (ompact form of DNA induced by spermidine. Nature (London), 259. 333-335.

Grosberg, A. Yu., Erukhimovitch, I. Ya.\& Shakhnovitch E. I. (1982). On the theory of $\Psi$-condensation. Biopolymers. 21. 2413-2432.

Herkovits. T. T., Singer, S. J. \& Geiduschek. E. J. (1961) Non aqueous solutions of DNA. Denaturation in methanol and ethanol. Arch. Biochem. Biophys. 94. $99-114$

Hinnebusch. A. G. Clark, V. F. \& Klot\%, L. ( . (1978) Length dependence in reassociation kinetics of radioactive tracer DNA. Biochemistry, 17. 1521-1529

Holliday, R. (1990). The history of DNA heteroduplex. BinEssays, 12, 133-142.

Huey. R. \& Mohr. S. ( С (1981). Condensed states of nucleic acids. III. $\Psi(+)$ and $\Psi(-)$ conformational transitions of DNA induced by ethanol and salt. Biopolymers, 20, 2532-2552.

Jarvis, T. (., Ring, I). M., Daube, S. S. \& von Hippel, P. H. (1990). "Macromolecular crowding": thermodynamic consequences for protein protein interactions within the T4 DNA replication complex. J. Biol. Whem 265. 15160-15167.

Jordan. C. F., Lerman, L. S. \& Venable. . . H. , J (1972). Structure and circular dichroism of DNA in concentrated polymer solutions. Nature Now Biol. 236. $67-70$.

Joyce ( $\mathrm{x} . \mathrm{F}$. (1989). RNA evolution and the origins of life. Nature (London), 338, 217-224.

Karpel. R. L.. Bertelsen. A. H. \& Fresco, .J. R. (1980). Stabilization of nucleic acid secondary structure by cationic metal complexes. Biochemistry. 19,504-512.

Kimizuka, H., Yamauchi, A. \& Mori. T. (1967). Selective interaction of dextran sulfate with inorganic cations. Bull. Chem. Soc. Jpn. 40, $1281 \cdot 1282$.

Kléman. M. (1989). Defects in liquid crystals. Rep. Prog. Phys. 52, 555-654.

Knoll, D. A. Fried, M. G. \& Bloomfield, I. A. (1986). 
Condensation of DNA by divalent cations at elevated temperatures. Biophys. J. 49, 301a.

Kohne, D. E., Levison, S. A. \& Byers, M. J. (1977). Room temperature method for increasing the rate of DNA reassociation by many thousandfold: the phenol emulsion reassociation technique. Biochemistry, 16, 5329-5341.

Kornberg, A. (1980). DNA Replication. Freeman, San Francisco,

Laemmli, U. K. (1975). Characterization of DNA condensates induced by poly (ethylene oxide) and polylysine. Proc. Nat. Acad. Sci., U.S.A. 72, 4288-4292.

Laurent. T. C. Preston, B. N. \& Carlsson, B. (1974). Conformational transitions of polynucleotides in polymer media. Eur. J. Biochem. 43, 231-235.

Lerman, L. S. (1971). A transition to a compact form of INA in polymer solutions. Proc. Nat. Acad. Sci., U.S.A. 68, $1886-1890$.

Lerman, L. S. (1973). The polymer and salt-induced condensation of DNA. In Physico-Chemical Properties of Nucleic Acids (Duchesne, J., ed.), vol. 3, Academic Press, New York.

Lerman, L. S. \& Allen, S. L. (1974). Chromosomal analogues: long-range order in $\psi$-condensed DNA. Cold Spring Harbor Symp. Quant. Biol. 38, 59-73.

McCarthy, J. G.. Sander, M., Lowenhaupt, K.\& Rich, $\Lambda$. (1988). Sensitive homologous recombination strandtransfer assay: partial purification of a Drosophila melanogaster enzyme and detection of sequence effects on the strand-transfer activity of RecA protein. Proc. Nat. Acad Sci. U.S.A. 85, 5854-5858.

Manning, G. S. (1978). The molecular theory of polyelectrolyte solutions with applications to the electrostatic properties of polynucleotides. Quart. Rev. Biophys. 11. $179-246$.

Manning, G. S. (1989). Self-attraction and natural curvature in null DNA. J. Biomol. Struct. Dynam. 7, 41-61.

Marmur, J. \& Doty, P. (1961). Thermal renaturation of deoxyribonucleic acids. J. Mol. Biol. 3, 585-594.

Marx. K. A. \& Reynolds, T. C. (1982). Spermidinecondensed $\phi \mathrm{X} 174$ DNA cleavage by micrococcal nuclease: torus cleavage model and evidence for unidirectional circumferential DNA wrapping. Proc. Nat. Acad. Sci., U.S.A. 79, 6484-6488.

Minton, A. P. (1981). Excluded volume as a determinant of macromolecular structure and reactivity. Biopolymers, 20, 2093-2120.

Minton, A. P. (1983). The effect of volume occupancy upon the thermodynamic activity of proteins: some biochemical ronsequences. Mol. Cell. Biochem. 55, $119-140$

Odijk. T. (1983). On the statistics and dynamies of confined or entangled stiff polymers. Macromolecules, 16, 1340-1344.

Odijk. T. (1986). Theory of lyotropic polymer liquid (rystals. Macromolecules, 19, 2313-2329.

Onsager, T. (1949). The effects of shape on the inter actions of colloidal particles. Ann. N.Y. Acad. Sci. 51. $627-659$

Pauling. L. \& Delbrück, M. (1940). The nature of the intermolecular forces operative in biological proresses. Science, 92, 77-79.

Podgornik, R.. Rau, D. C. \& Pargesian, V. A. (1989). The action of interhelical forces on the organization of DNA double-helices: fluctuation-enhanced decay of electrostatic double-layer and hydration forces. Macromolecules, 22, 1780-1786.

Pontius. B. W. \& Berg, P. (1990). Renaturation of complementary DNA strands mediated by purified mammalian heterogeneous nuclear ribonucleoprotein Al protein: implications for a mechanism for rapid molecular assembly. Proc. Nat. Acad. Sci, U.S.A.87, 8403-8407.

Post, C. B. \& Zimm, B. H. (1982). Theory of DNA condensation: collapse versus aggregation. Biopolymers, 21, 2123-2137.

Radding, C. M. (1989). Ilelical RecA nucleoprotein filaments mediate homologous pairing and strand exchange. Biochim. Biophys. Acta, 1008, 131-145.

Reddy, M. R. \& Berkowitz, M. (1989). Hydration forces between parallel DNA double helices: computer simulations. Proc. Nat. Acad. Sci., U.S.A. 86, 31653168.

Richter, P. H. \& Eigen, M. (1974). Diffusion controlled reaction rates in spheroidal geometry. Application to repressor-operator association and membrane bound enzymes. Biophys. Chem. 2, 255-263.

Riggs, A. D., Bourgeois, S. \& Cohn, M. (1970). The lac repressor-operator interaction. III. Kinetic studies. J. Mol. Biol. 53, 401-417.

Schiedner, G., Wessel, R., Scheffner, M. \& Stahl, H. (1990). Renaturation and DNA looping promoted by the SV40 large tumour antigen. EMBO J. 9, 2937 2943 .

Srivenugopal, K. S., Wemmer, D. E. \& Morris, D. R. (1987). Aggregation of DNA by analogs of spermidine: enzymatic and structural studies. Nucl. Acids Res. 15, 2563-2580.

Stanley, H. E. (1987). Introduction to Phase Transitions and Critical Phenomena. Oxford University Press.

Studier, F. W. (1969a). Conformational changes of singlestranded DNA. J. Mol. Biol. 41, 189-197.

Studier, F. W. (1969b). Effects of the conformation of single-stranded DNA on renaturation and aggregation. J. Mol. Biol. 41, 199-209.

Svaren. J.. Inagami. S.. Lovegren. E. \& Chalkley, R. (1987). DNA denatures upon drying after ethanol precipitation. Nucl. Acids Res. 15, 8739-8754.

Tikchonenko. T. T., Dobrov, E. N., Velikodvorskaya, G. A. \& Kisseleva, N. P. (1966). Pecularities of the secondary structure of phage DNA in situ. J. Mol. Biol. 18, 58-67.

Tikchonenko, T. I., Budowsky, E. I., Sklyadneva, V. B. \& Khromov, I. S. (1971). The secondary structure of bacteriophage DNA in situ. III. Reaction of $S_{d}$ phage with o-methylhydroxylamine. $J$. Mol. Biol. 55 . $535-547$.

Vogelstein. B. \& Gillespie, D. (1979). Preparative and analytical purification of DNA from agarose. Proc. Nai. Acad. Sci., U.S.A. 76. 615-619.

von Hippel, P. H. \& Bery, O. G. (1990). Favilitated target location in biological systems. I. Biol. Chem. 264 $675-678$

Wang, J. C. (1979). Helical repeat of DNA in solution. Proc. Nat. Acad. Sci. I.S.A. 76, 200-203.

Weinstock, G. M., MeEntec, K. \& Lehman. I. R. (1979). ATP-dependent renaturation of DNA catalysed by the RecA protein of Escherichia coli. Proc. Nat. Acad Sci., U.S.A. 76, 126-130.

Wetmur, J. G. (1976). Hybridization and renaturation kinetirs of nucleic acids. Annu. Rev. Riophys. Rioeng 5. $337-361$

Wetmur. J. G. \& Davidson, N. (1968). Kinetics of renaturation of DNA. $J$. Mol. Biol. 31, 349-370.

Widom, J. \& Baldwin, R. L. (1983). Monomolecular condensation of $\lambda$-DNA induced by cobalt hexam mine. Biopolymers, 22, 1595-1620.

Wieder, R. \& Wetmur, J. G. (1981). One hundred-fold 
acceleration of DNA renaturation rates in solution. Biopolymers, 20, 1537-1547.

Wieder, R. \& Wetmur, J. G. (1982). Factors affecting the kinetics of DNA reassociation in phenol-water emulsion at high DNA concentrations. Biopolymers, 21. 665-677.

Williams, C., Brochard, F. \& Frisch, H. L. (1981). Polymer collapse. Annu. Rev. Phys. Chem. 32, 433-451.

Wilson, D. H., Price, H. L., Henderson, J., Hanlon, S. \& Benight, A. S. (1990). Structure and dynamics of M13mpl9 circular single-strand DNA: effects of ionic: strength. Biopolymers, 29, 357-376.

Wilson, R. W. \& Bloomfield, V. A. (1979). Counterion- induced condensation of deoxyribonucleic acid. A light-scattering study. Biochemistry, 18, 2192-2196.

Yevdokimov, Yu. M., Skuridin, S. G. \& Salyanov, V. I. (1988). The liquid-crystalline phases of doublestranded nucleic acids in vitro and in vivo. Liq. Crystals, 3, 1443-1459.

Zimmerman, S. B. \& Harrison, B. (1987). Molecular crowding increases binding of DNA polymerase to DNA: an adaptative effect. Proc. Nat. Acad. Sci.. U.S.A. 84, 1871-1875.

Zimmerman, S. B. \& Pheiffer, B. H. (1979). Helical parameters of DNA do not change when DNA fibers are wetted: X-ray diffraction study. Proc. Nat. Acad. Sci., U.S.A. 76, 2703-2707.

Edited by P. H. von Hippel 